\title{
BUSINESS PROCESSES IMPROVEMENT IN E-SUPPLY CHAINS
}

\author{
Dragana Rejman Petrovic* \\ University of Kragujevac, Faculty of Economics, Kragujevac, The Republic of Serbia
}

\begin{abstract}
The development of a model to improve business processes in e-supply chains involves the use of a process approach to and a methodology for information systems development and includes the definition of the requirement, logical key process modeling with the defined information flow within the logical subsystem, logical data modeling, the logical network and data distribution modeling, and the logical interface modeling in order to meet different users' needs. In doing so, a variety of methods and techniques for the different development stages of management information systems are used, namely: the business process management, the business process performance management and the analytic hierarchy process as a method for multiple-criteria decision making. This paper analyzes business processes and different types of supply chains in the automotive industry, as the representative of complex systems. Based on the selected key business processes and key performance indicators of business processes, the analytic hierarchy process model is developed, followed by their optimization. The result is the management information system model intended to improve the key business processes in e-supply chains. The research results show that the performance improvement of business processes in e-supply chains, the application of the model to improve the key business processes and the application of Web-based information and communication solutions affect the efficiency and quality of e-supply chains.
\end{abstract}

Keywords: supply chains, business processes, performance measurement, management information systems.

JEL Classification: M10, M15, M21

\section{INTRODUCTION}

The supply chain is not only focused on specific functions in organizations, such as procurement, production and delivery, but also on the improvement of the system performance in the internal and the external environments. In the competitive

\footnotetext{
*Correspodence to: D. Rejman Petrovic, University of Kragujevac, Faculty of Economics, Dj. Pucara 3, 34000

Kragujevac, The Republic of Serbia; e-mail: rejman@kg.ac.rs
}

environment of the 21st century, organizations in the supply chain need to ensure efficiency, a high level of service, a fast response and a high quality of products and services. Supply chain management assumes the holistic and the strategic approaches to the processes of demand, production, procurement and logistics. The supply chain concept has substantially changed the nature of the organization. Control is no longer based on the direct control of the business processes of individual organizations, but rather on the control 
of all the processes among integrated organizations as members of the supply chain. Coordination among organizations in the supply chain is the key to its effective implementation. It is necessary for organizations to become aware of their role and activities in the supply chain and the fact that their performance affects the performance of the other members of the supply chain. This means that organizations need to manage the supply chain performance to achieve a competitive advantage.

The present work shows the model developed for measuring the performance of the key business processes in e-supply chains, which provides for the improved efficiency and quality of the entire supply chain. The development of the model for measuring the performance of the key business process of the e-supply chain started from the concept of quality management in supply chains. The process of quality management in supply chains involves the measurement, analysis and continuous improvement of products, services and business processes, as well as the coordination and integration of the business processes of all member organizations in the supply chain. The developed performance measurement model provides a structured approach to quality in supply chains, which includes the required and defined quality level of the chain network design, the quality of procurement, sales and logistics processes, as well as the use of resource planning systems in organizations. The quality and efficiency of each business process is measured based on the analyzed, selected and defined key performance indicators, which have different relative importance in different types of supply chains.

The developed model was tested in the member organizations of the automotive industry's supply chains and included the organization-suppliercustomer sequence, which recurs in the context of the supply chain, because each organization in the supply chain has its own suppliers and customers. Starting from the above facts and assumptions, the developed model becomes applicable to each member in the supply chain.
In the new approach, the author focuses on calculating the key performance indicators, identifying gaps, depending on the actual and target values of the key performance indicators belonging to a particular performance attribute (quality - Q, costs - C, delivery - D and flexibility - F), as well as on the calculation of the overall performance of different types of supply chains (efficient, lean, fast and hybrid) as a result of the integrated key performance indicators and their relative importance in relation to the particular type of the supply chain. In fact, assessing all the key business processes in the supply chain, by using the selected and defined key performance indicators and their different priorities, leads to an overall supply chain performance measurement. This approach allows the management, both at the level of the supplier-organization-customer sequence and the level of original equipment manufacturers (OEM), as the supply chain owners, to track, analyze and identify the critical spots and links in the supply chain, as well as various simulations in this regard, in order to improve business processes in e-supply chains.

The research subject presented in this paper is the business processes in e-supply chains and the ways to enhance them, as well as the improvement of the overall network of business processes.

The objective is to develop a model for improving the performance of e-supply chains by improving the performance of the key business processes, supported by information and communication solutions.

Based on the determined research subject and objective, the paper sets up the following hypotheses:

H1: The modeling of business processes and performance can define the key business processes in e-supply chains;

H2: Using the Web-based information and communication solutions can improve the performance of business processes in e-supply chains. 
H3: Improving the performance of the key business processes affects the efficiency and quality of e-supply chains.

To develop a management information system model to measure the performance of business processes in e-supply chains, the methods supporting individual or multiple stages in the lifecycle of the information system development are used, such as: the system development life cycle (SDLC), the business system planning (BSP), the structured systems analysis (SSA), the structured systems analysis and design method (SSADM), the object-oriented analysis (OOA), the data flow diagram (DFD), the entity relationship model (ERM). In order to evaluate and rank supply chains, the multiple-criteria decisionmaking method is used - the Analytic Hierarchy Process (AHP). This results in the improvement of the data model, in terms of the applied AHP model requirements.

The paper consists of five sections. After the Introduction, the importance of the performance measurement of business processes in supply chains and the link between the priorities of the different types of performance measures and certain types of the supply chain are pointed out. The third section presents the planning and development of information systems to support and improve business processes in e-supply chains. The fourth section gives the key research results. The fifth section summarizes the concluding remarks, indicates the theoreticalmethodological and practical contribution of the paper and defines possible directions for further research.

\section{MEASURING BUSINESS PROCESS PERFORMANCE IN SUPPLY CHAINS}

With the increasing number of inputs, as well as an increase in the volume of control and the increasing complexity of operations, data management (DM) and data use are becoming more complex. Events produce data and each piece of such data is a potential indicator, whereas just a few indicators are considered as the key performance indicators (KPI) (Karadgi, 2014)
All members of the supply chain, upstream and downstream, are the participants that have an impact on the supply chain performance (e.g. quality, delivery, the cost, flexibility). The need to determine the appropriate type of the supply chain performance measure is vital, as it will, and as such, influences decision making. For example, if a measure does not provide accurate and relevant information on the process to be measured, it can lead to wrong decisions followed by counterproductive actions. A large number of studies emphasize the need for the right type of performance measures in supply chains (Otto \& Kotzab, 2001; Shepherd \& Günter, 2006; Vereecke \& Muylle, 2006; Koh, Demirbag, Bayuraktar, Tatoglu, \& Zaim, 2007; Bai \& Sarkis, 2012; Bai, Sarkis, Wei \& Koh, 2012; Cabral, Grilo \& Cruz-Machado, 2012; Gimenez \& Tachizawa, 2012; Genovese, Lenny Koh, Kumar \& Tripathi, 2014). The results obtained through the conducting of these studies indicate various selected, defined and tested performance measures used among organizations.

The area of the supply chain performance has been widely covered in the literature (Holmberg, 2000; Lambert \& Pohlen, 2001; Landeghem van \& Persoons, 2001; Tracey \& Tan, 2001; Petroni \& d Panciroli, 2002; Chan \& Qi, 2003; Gunasekaran, Patel \& McGaughey, 2004; Morgan, 2004). These studies highlight the need for measuring the effectiveness of an integrated supply chain.

A. Petroni and B. Panciroli (2002) claim that customers typically retain the suppliers that achieve the highest overall performance, expressed through the price, quality, production flexibility and the delivery time. A. De Toni, G. Nassimbeni and S. Tonchia (1994) argue that an effective supply chain depends on achieving a high level of performance in terms of the cost, the quality and the lead time. R. H. Hayes and S. C. Wheelwright (1984) were the first to introduce the methods for achieving an operational strategy by using the four dimensions that the organization chooses in order to compete within the target market, such as quality, the price, flexibility and delivery. Their original formulation was applicable to all functions.

D. M. Lambert and R. L. Pohlen (2001) argue that a well-designed measurement system in the supply 
chain can lead to a competitive advantage through the differentiation of services and lower costs. They also believe that the implementation of the supply chain strategy requires the metrics that balances performance and the goals of the other members in the supply chain. The supply chain performance can be regarded as a system of measures, such as quality, delivery, flexibility and cost/price. The traditional performance measures, such as profitability, are less relevant for measuring the performance of the supply chain.

Establishing a measurement system requires the knowledge of the processes within the organization and between customers and suppliers. In order to generate this knowledge, the organization has to decide which performance measures will be taken into consideration. I. Robson (2004) states that, "without knowing the exact circumstances under which the system of measuring will lead or not lead to performance improvement, it is difficult to justify the additional cost of implementing the system of measurement".

The performance measurement system in the supply chain consists of a set of parameters that can completely describe logistics and production performance in the entire supply chain, both from the perspective of end customers and any other member in the supply chain. However, there are a number of performance measures and attributes in the supply chain that can be evaluated. The most commonly used in practice, as well as the most cited in the research, are the following measure attributes: quality, delivery, cost/price and flexibility.

Given the fact that there are different types of supply chains and that supply chains have different characteristics, they as such require individual attention in order to achieve the optimal performance of the supply chain (Christopher \& Towill, 2000; Mason \& Cole, 2002; Saad \& Patel 2006; Christopher, Peck $\&$ Towill, 2006). Certain supply chain performance measures will be prioritized, depending on the type of the supply chain.

In an efficient supply chain, the primary performance measures are costs, such as total costs, ranging from the supplier, via the internal supply chain, to the customer, i.e. all kinds of costs that have an impact on production costs. An agile supply chain reacting quickly to market demands has a shorter lead time, so that in this type of the supply chain the primary measure is delivery, only to be also followed by the flexibility (mix) of production and the product quality. A shorter lead time from order to delivery is yet another important measure in the lean supply chain. The hybrid supply chain is focused on shortening time without creating additional costs in order to adapt to customers' requirements, so that the primary performance measures are delivery, flexibility and quality.

This establishes a link between the priorities of different types of performance measures in the supply chain and the supply chain of a certain type, which is the basis for developing a model for improving the performance of business processes in e-supply chains.

\section{THE PLANNING AND DEVELOPMENT OF THE INFORMATION SYSTEM FOR SUPPORTING AND IMPROVING BUSINESS PROCESSES IN E-SUPPLY CHAINS}

In the process of planning and developing information systems in order to support and improve business processes in e-supply chains, the following methods are used: the business system planning (BSP) method, the structured system analysis (SSA) method, the database management systems (DBMS) method (Arsovski, 2013) and the analytic hierarchy process (AHP), as a method for multiple-criteria decision making (Saaty, 2010).

By using the BSP method, based on stakeholders' requirements and needs for the performance improvement of business processes in e-supply chains, the following is achieved:

- organization and the supply chain business objectives are modelled, along with the objectives of the information system, in order to improve 
the performance of business processes in e-supply chains,

- the key business processes in the organization and supply chains are identified, as well as the procedures and the guidelines regulating the method of the execution of processes and activities, authorities and responsibilities, terms, documentation, standards, reports for different levels of management and decision making, resources and so forth,

- a generic logical model of the key processes and data in order to support the information system is developed so as to improve the performance of business processes in e-supply chains.

Using the SSA method, with the help of the ERwin and BPwin software tools, a detailed logical process model, a detailed logical data model and an interface model are developed.

Using the database management system, the logical data model is transformed into a database, thus achieving data consistency, eliminating data redundancy and ensuring data protection from unauthorized access.

By using the AHP method, a model for the evaluation of supply chains and their ranking according to the selected criteria is developed in order to, based on the supply chain performance, see the ranking of the supply chain and decide where reaction is needed to improve its performance.

\section{Model of Stakeholders' Requirements for the Management of the Performance Business Processes in e-Supply Chains}

ZIn order to develop a model for the management information system for measuring and improving the performance of business processes in e-supply chains, stakeholders' requirements for the improving of the performance of the business processes in e-supply chains are defined in the first place.

Requirement modeling is the basis for defining an approach to and a strategy for the development of the information system, so that in this process the collection of requirements and meeting the user's needs are a very important activity. The modeling process requires an analysis of stakeholders' different requirements.

The process of the analysis and recording of such requirements includes the identification of all requirements aimed at improving the key processes in the supply chain, which in any way affect or will be affected by the future system. Due to various stakeholders' different requirements, it is necessary to categorize them.

Stakeholders may be internal and external. Internal stakeholders are an organization's managers, employees and owners. External stakeholders are OEM, customers, suppliers, business partners, banks, as well as the community, government agencies, various non-governmental organizations and so on.

In order to define and analyze stakeholders' requirements, the author applies interviews, analyzes work done in a specific environment and studies the documentation. In order to develop the requirement model, the following stakeholders are selected: the management, the owners, suppliers, customers and OEM.

In terms of improving the performance of the business processes in e-supply chains, the requirements and needs coming from the management of the organization refer to the efficiency of the information system in respect of the automated and efficient generation of different types of reports on the key performance indicators for different business processes. Also, the management have their own needs and requirements for the use of the method for conducting a multiplecriteria analysis and optimization, which in this case is the AHP model, given the fact that decisions made by the management are complex and usually inclusive of multiple conflicting criteria. This enables managers, in the case of the occurrence of complex problems with a number of alternative criteria, to relatively easily establish relationships between the influencing factors, recognize their explicit or relative influence and importance in real conditions and determine the dominance of one factor over another. The requirements and needs of the management are formulated as a possibility of: 
- monitoring the key business processes, which in this case are procurement, sales and logistics;

- measuring and analyzing their key performance indicators at different time intervals;

- measuring and analyzing the overall performance of different types of supply chains at various time intervals, and

- evaluating, ranking and comparing different types of supply chains.

For the owners, the selected requirements and needs for information relate to the amount of return on the invested capital and a long-term sustainable capital increase, the sales growth percentage, the percentage of a reduction of or an increase in the cost of transportation and the supply chain optimization.

For suppliers, the chosen requirements and needs relate to:

- the defined product/service delivery specifications,

- electronic data interchange, or EDI order receipt (EDI - Electronic Data Interchange), forecasting the ability for a period of six months,

- exchange of information on the actual key performance indicators of the business processes and their target values,

- information about the weights of the key performance indicators for the appropriate type of the supply chain.

For customers, the chosen requirements and needs relate to: information about the product quality, the conformity of the delivery quality, the deadlines, the acceptability of the product price, the price/ quality ratio, the availability of the required amount of the product/number of the provided services, the availability of information on products/services, the availability of information on the status of orders, the way of dealing with complaints, the exchange of information on the generated key performance indicators of the business processes and their target values, and information on the weights of the key performance indicators for the appropriate type of the supply chain. Customers articulate their requirements through the 100/0/30 principle, which means that the organization, as the supplier, must ensure $100 \%$ ontime delivery, with 0 ppm (non-conforming parts per million produced) no later than 30 days after the launch of production. In order to achieve this, the organization must impose such requirements on its suppliers in order to meet customer requirements.

For OEM as the owner of the supply chain, the chosen requirements and needs relate to access to information about all supply-chain member organizations' required key performance indicators in the defined form.

The model of stakeholders' requirements for the performance management of business processes in the e-supply chain is shown in Figure 1.

The analysis of user requirements is carried out for all the three management levels: strategic, tactical and operational. Based on the specification of requirements for information at all management levels, the systematization and specification of information needs per business processes is carried out, based on which interface modeling for management purposes is performed. Given the different characteristics of tasks and different information for each management level, the definition and analysis of user requirements is based on the fact that different management and decision-making levels set specific requirements in terms of the volume and type of information that should be provided to them. Diversity refers to the necessary indicators and information, the period of the submission of the required information and the form of information, as accounted for in Table 1.

The analysis of user requirements is carried out for all the three management levels: strategic, tactical and operational. Based on the specification of requirements for information at all management levels, the systematization and specification of information needs per business processes is carried out, based on which interface modeling for management purposes is performed. Given the different characteristics of tasks and different information for each management level, the definition and analysis of user requirements is based on the fact that different management and decision-making levels set specific requirements in terms of the volume and type of information that 


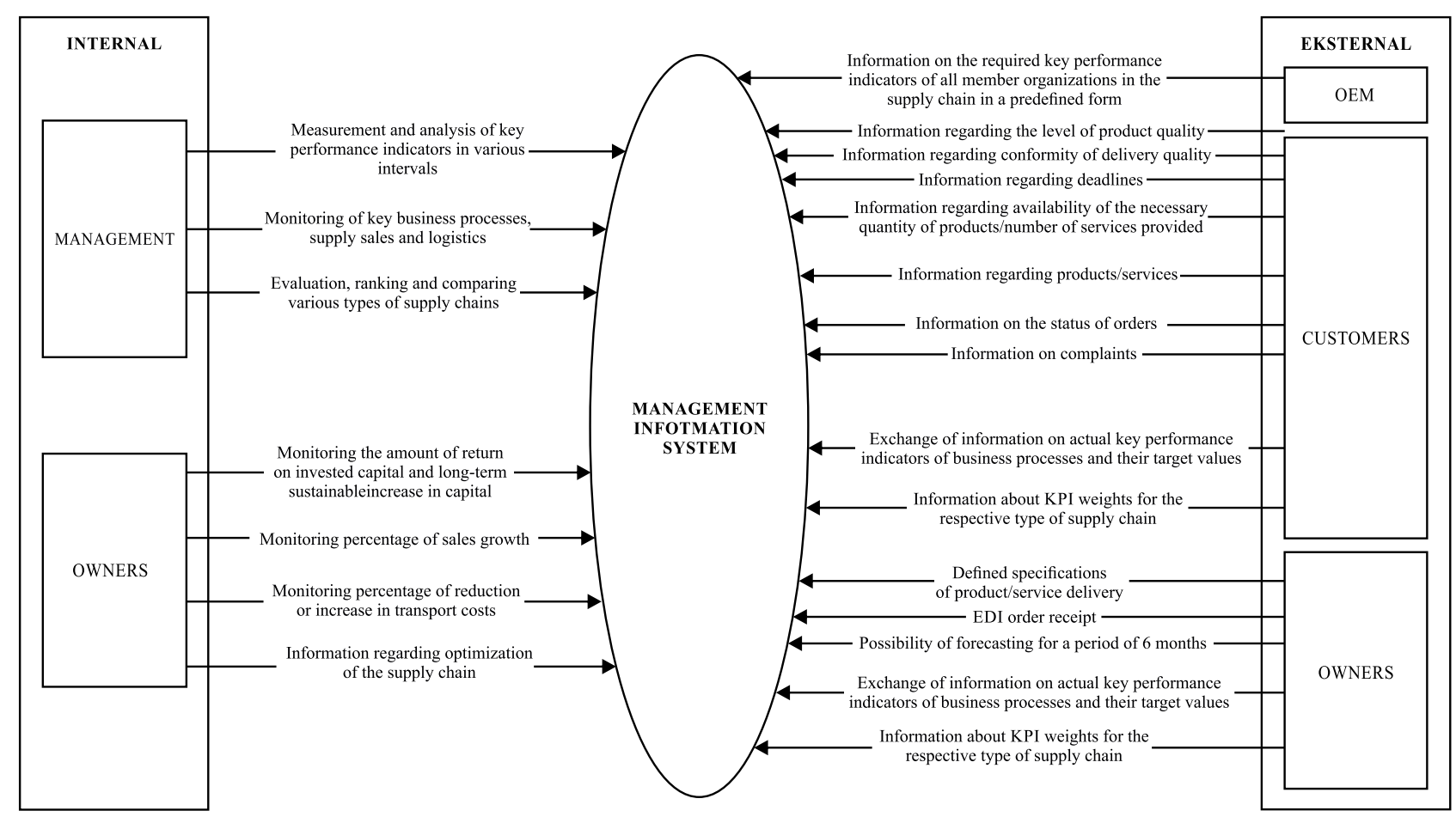

Figure 1 The model of stakeholders' requirements for the performance management of business processes in the e-supply chain

\section{Source: Author}

should be provided to them. Diversity refers to the necessary indicators and information, the period of the submission of the required information and the form of information, as accounted for in Table 1.

The analysis of user requirements is carried out for all the three management levels: strategic, tactical and operational. Based on the specification of requirements for information at all management levels, the systematization and specification of information needs per business processes is carried out, based on which interface modeling for management purposes is performed. Given the different characteristics of tasks and different information for each management level, the definition and analysis of user requirements is based on the fact that different management and decision-making levels set specific requirements in terms of the volume and type of information that should be provided to them. Diversity refers to the necessary indicators and information, the period of the submission of the required information and the form of information, as accounted for in Table 1.

Beside the usual and widespread practice regarding management requirements, there is a tendency for new management requirements in terms of the evaluation and ranking of the supply chain, so that they are associated with and integrated into a developed and presented model for the improvement of business processes in e-supply chains, which is a step forward of this management information system.

\section{Process Modeling in e-Supply Chains}

For planning and developing an information system, the key phase is the analysis, the selection of the key processes and defining business processes. Accurately selected and defined business processes determine the quality of the 
projected information system. In order for an information system to be independent of future organizational changes in the business system, it is necessary that it be based on processes rather than organizational units, i.e. business system functions. In addition, processes enable a better understanding and facilitate the analysis of the functioning of the business system.

Table 1 The systematization and specification of information needs per business processes

\begin{tabular}{|c|c|c|c|c|}
\hline 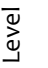 & Processes & Indicators & Time interval & Form \\
\hline 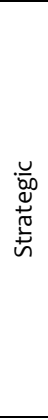 & Supply chain & $\begin{array}{l}\text { Total ranking of identified types of supply chain } \\
\text { Ranking of different types of supply chains } \\
\text { KPI priorities according to types of supply chains } \\
\text { Influence of change in relative importance of } \\
\text { different criteria on the supply chain ranking } \\
\text { Influence of change in priorities of individual KPI } \\
\text { on the supply chain ranking } \\
\text { Evaluation and ranking of suppliers depending } \\
\text { on the type of the supply chain } \\
\% \text { of the cost of procurement in net proceeds } \\
\text { from sale (NPS) } \\
\text { Sales growth } \\
\% \text { of transport costs in net proceeds from sale } \\
\end{array}$ & $\begin{array}{l}\text { Quinquennial, annually, } \\
\text { and quarterly }\end{array}$ & 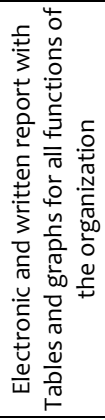 \\
\hline $\begin{array}{l}\underset{\mathscr{J}}{\mathscr{U}} \\
\stackrel{\sigma}{\leftarrow}\end{array}$ & Sale & \begin{tabular}{|l|} 
Procurement costs \\
Procurement by suppliers \\
Complaints to suppliers \\
Supplier OTD (On-time delivery) \\
Supplier PPM (share of non-conforming parts per \\
million produced) \\
Supplier DMR (discrepant material report) \\
Cost of poor quality of suppliers \\
Assessment of suppliers \\
Realized sales \\
Sale by customers \\
Customer complaints \\
OTD (On-time delivery) \\
PPM (share of non-conforming parts per million \\
produced) \\
DMR (discrepant material report) \\
Cost of poor quality \\
Assessment of organization by the customer \\
Total transport costs \\
Regular and extraordinary transport costs \\
Transport costs for each service provider \\
Complaints by service \\
Assessment of service provider
\end{tabular} & Quarterly and monthly & 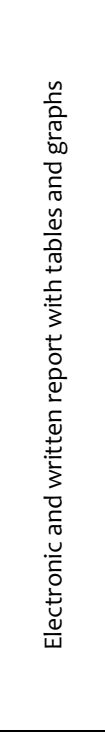 \\
\hline $\begin{array}{l}\overline{0} \\
\frac{0}{0} \\
\stackrel{0}{+0} \\
\frac{0}{0} \\
0\end{array}$ & Procurement & \begin{tabular}{|l|} 
Supplier OTD (On-time delivery) \\
Supplier PPM (share of non-conforming parts per \\
million produced) \\
DMR (discrepant material report) \\
Cost of poor quality of suppliers \\
OTD (On-time delivery) \\
Supplier PPM (share of non-conforming parts per \\
million produced) \\
DMR (discrepant material report) \\
Cost of poor quality \\
Total transport costs \\
Transport costs inbound regular \\
Transport costs inbound extraordinary \\
Transport costs outbound regular \\
Transport costs outbound extraordinary
\end{tabular} & Weekly and daily & 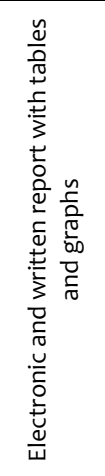 \\
\hline
\end{tabular}

Source: Author 
In order to model business processes in the e-supply chain, one should consider the supply chain as a whole, which implies the integration of very large and complex multidisciplinary dependent processes and information. Processes in the supply chain in the automotive industry begin with the procurement of resources, continue with the process of production, assembly, storage and transport, and end with the delivery of the finished product to the end customer.

In accordance with the subject of this research, referring to business processes in e-supply chains, identifying the ways to improve the network of business processes and developing models for improving the performance of business processes in e-supply chains, the supply chains of organizations operating in the automotive industry belonging to Tier 3 are analyzed.

Bearing in mind the defined and determined key performance indicators the basis for defining the structure of management information systems in order to improve the performance of business processes in e-supply chains lies in the processes of procurement, sales and logistics. Within each module, the subsystems for measuring performance are defined, which enables the organization's management to access information on actual key performance indicators for each business process. The modules can be administered alone, whereas the real power of the information system to measure the performance of business processes in e-supply chains lies in the synergy of integrated modules, because in this way it allows the integrated measurement of the supply chain performance.

The main task of the procurement process is to achieve the seven major goals: the right product/service, the right quantity, the right conditions, the right supplier, the right time, the right service and the right place, on the basis of which it can be concluded that it is the procurement process that ensures the continuity of the realization of all other processes in the organization. Also, a detailed analysis of the literature on the key performance indicators shows that the key measures to monitor the supply chain performance are the product quality (through quality conformity, quality reliability and the final product quality), delivery (the delivery time, delivery reliability, delivery frequency, delivery synchronization, the delivery speed), and transport costs (through a comparison of the actual delivery costs - inbound, and shipping costs - outbound, and their share in the total transport costs, as well as a comparison of regular and extraordinary inbound and outbound costs).

Since these measures describe performance across organizational boundaries and measure the performance of the entire supply chain, including links to suppliers and to customers, a prerequisite for the measurement and analysis of the key supply chain performance is the existence of an information system that tracks operations, primarily the processes of procurement, sale, transport and customer complaints, because such a system can automatically lead to the selected key performance indicators.

In order to measure the performance of the defined supply chain, the following key performance indicators of the product quality, delivery quality and transport are selected:

- supplier key performance indicators: supplier ontime delivery (SOTD), discrepant material report (SDMR), parts per million (SPPM), cost of poor quality (SCPQ), the cost of inbound transport (regular costs and extraordinary costs) and

- the key performance indicators of the organization to the customer: on-time delivery (COTD), discrepant material report (CDMR), parts per million $(\mathrm{CPPM})$ the cost of poor quality (CCPQ), the cost of outbound transport (regular and extraordinary costs).

In this way, the organization is able to monitor and measure performance associated with its supplier and its procurement process, and also monitor and measure its performance related to its sale process, which is actually a link with its customer's procurement process, thus, through the assessment of its delivery process, obtaining information about the performance of the customers' procurement process. This, in turn, makes it possible to measure, monitor and analyze the performance of the supplierorganization-customer sequence in the supply chain, resulting in the improvement of the performance of the business processes in the supply chain. 


\section{Modeling the Subsystem, the Key Processes and Data Classes}

Based on the defined stakeholders' requirements (the management, the owners, customers, suppliers and OEM), the business process mapping in e-supply chains and the model for the improvement of the business process, the modeling of the key processes in e-supply chains is carried out. In order to develop the process models, the following methods are used:

- the BSP method, whose outputs are defined logical subsystems and key processes and data classes, and

- the SSA method, whose outputs are decomposed data flow diagrams (the context, the root and the primitive function diagram).

On the basis of the formed data processes/ classes matrix, the following logical subsystems are defined: the procurement subsystem (within it, the procurement contracting subsystem, the procurement planning subsystem, the procurement implementation subsystem, the performance measurement and evaluation of suppliers subsystem and the subsystem for measuring the performance of the procurement process), the sales subsystem (within it, the subsystem for measuring the performance of sales) and the logistics subsystem (within it, the subsystem for measuring the performance of the transport process).

Logical subsystems include data streams/data warehouse that the procurement, sales and logistics systems exchange internally with other subsystems in the organization, as well as externally, with business partners. Also, they include the corresponding key processes that generate, use and update certain documentation. The matrix shows only the new processes that improve the current situation and will, with the development of a new system, contribute to improving the performance of business processes in e-supply chains (Table 2).

In order to develop a system for measuring and improving the performance of business processes in supply chains, based on pre-defined procurement, sales and logistics processes, a level-based process hierarchy is defined, as well as the mutual dependence of the processes, with the help of the process/process matrix (Table 3).

For the purpose of developing a model to improve business processes in e-supply chains, the analysis focuses on the manufacturing organizations in the automotive industry that have introduced the ISO/ TS 16949 standard, which guarantees operation after the process approach and the existence of well-kept business processes. For the organizations observed, the decomposition of the three key processes (procurement, sales and logistics) is performed, where the processes are subjected to decomposition to the level necessary for the analysis, implementation and measurement of the processes in the supply chain. To describe the unfolding of each process, with the present relations between the processes, the processes and the sources, the processes and the destinations, as well as the processes and the internal data warehouses, the data flow diagrams are used. The data flow diagram is formed through:

- the context diagram (the 0 -th level),

- the medium-level diagram, and

- the primitive function diagrams at the lowest level, as shown in Figures 2, 3, 4 and 5.

The modeling of the business processes in the supply chain is controlled by the BPwin software tool for the modeling and analysis of complex business processes.

\section{Data Modeling in e-Supply Chains}

One of the important parts of the system analysis is the construction of a stable and complete data model in the observed business area. The organization uses hundreds of data types in its transactional processes. The data model is a means to achieve the logical interpretation of data in a particular area and allows one to understand the information content of such data. It can, therefore, be understood as a set of data structures and operations on these structures aimedat determining the logical database structure and the dynamic modeling of certain reality areas. 
Table 2 Logical subsystems and the key processes and data classes in e-supply chains

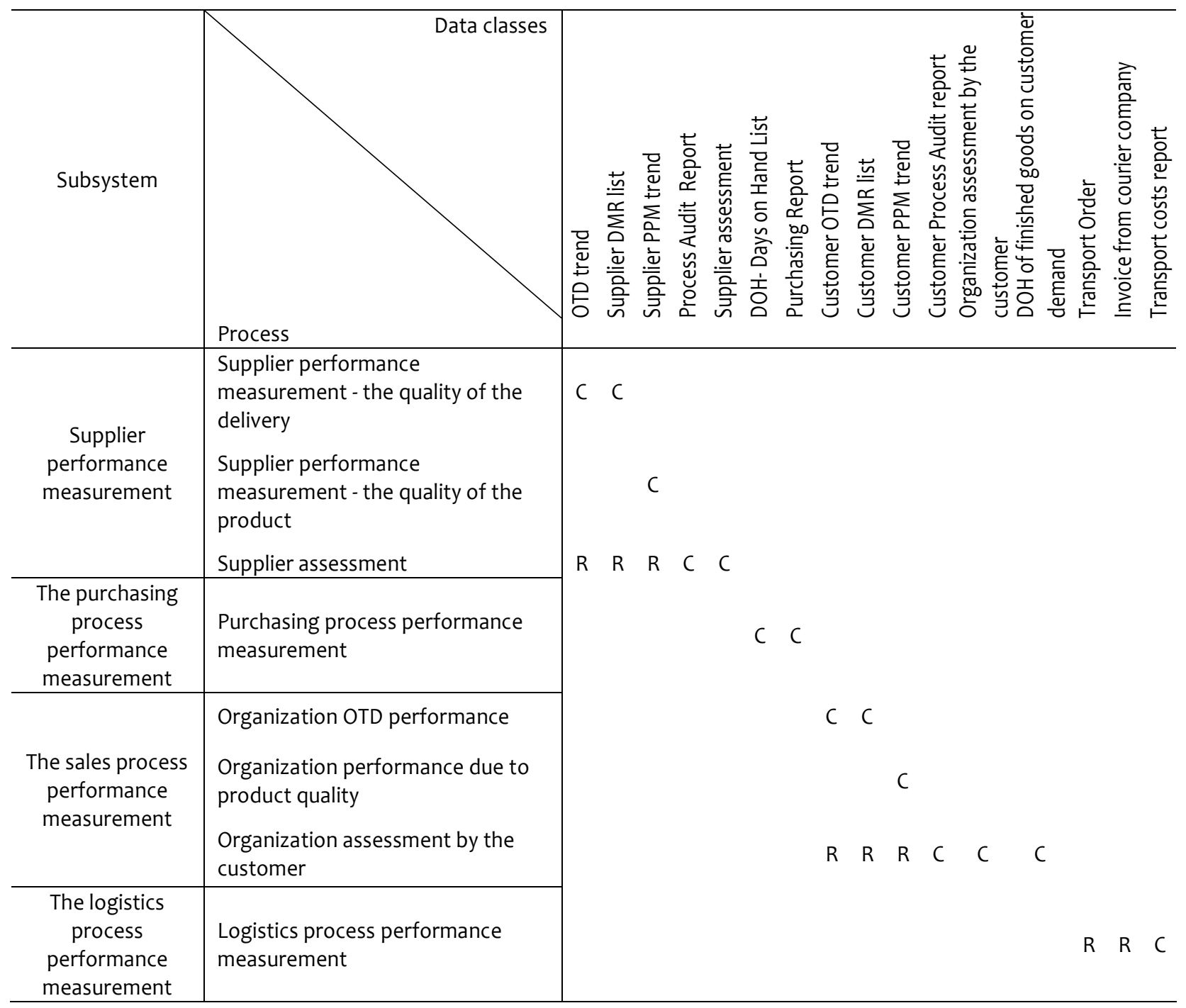

Source: Author

In the process of data modeling, one starts from the model of organization obtained in the phase of strategic information planning. A data model is generated through detailed process modeling, the analysis of data flows and documents and the identified needs for information important for the specific business area.

The data modeling procedure is carried out in three steps:
- the identification of all entity types on the basis of: the results of the modeling process, the results of the analysis of data flows, the flows and the content of documents, the results of the analysis of different applications, and the results of the analysis of the user's requested information needs;

- the establishing of the links and the types of the links between entities, as well as the model presentation through the entity relationship diagram; 


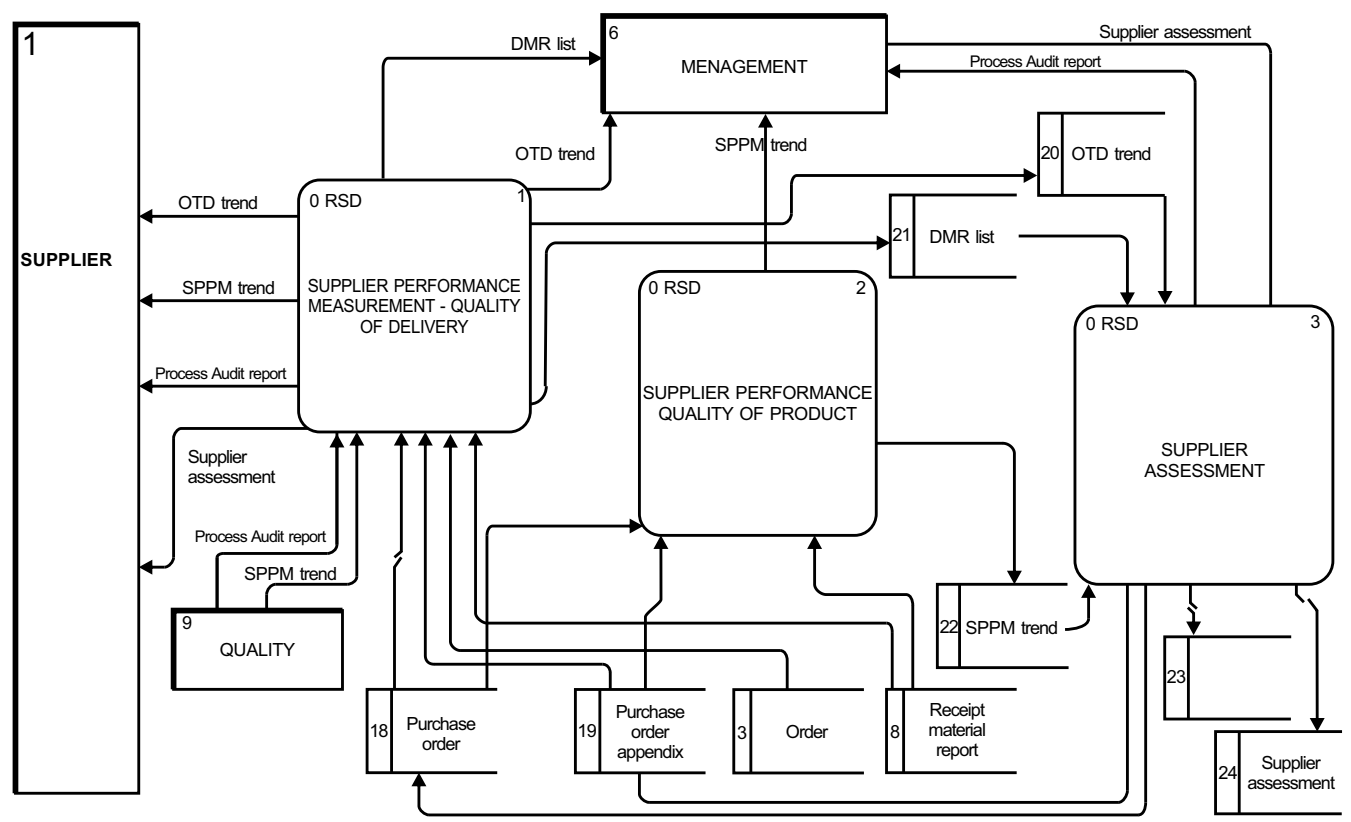

Figure 2 A data flow diagram - Supplier performance measurement

Source: Author

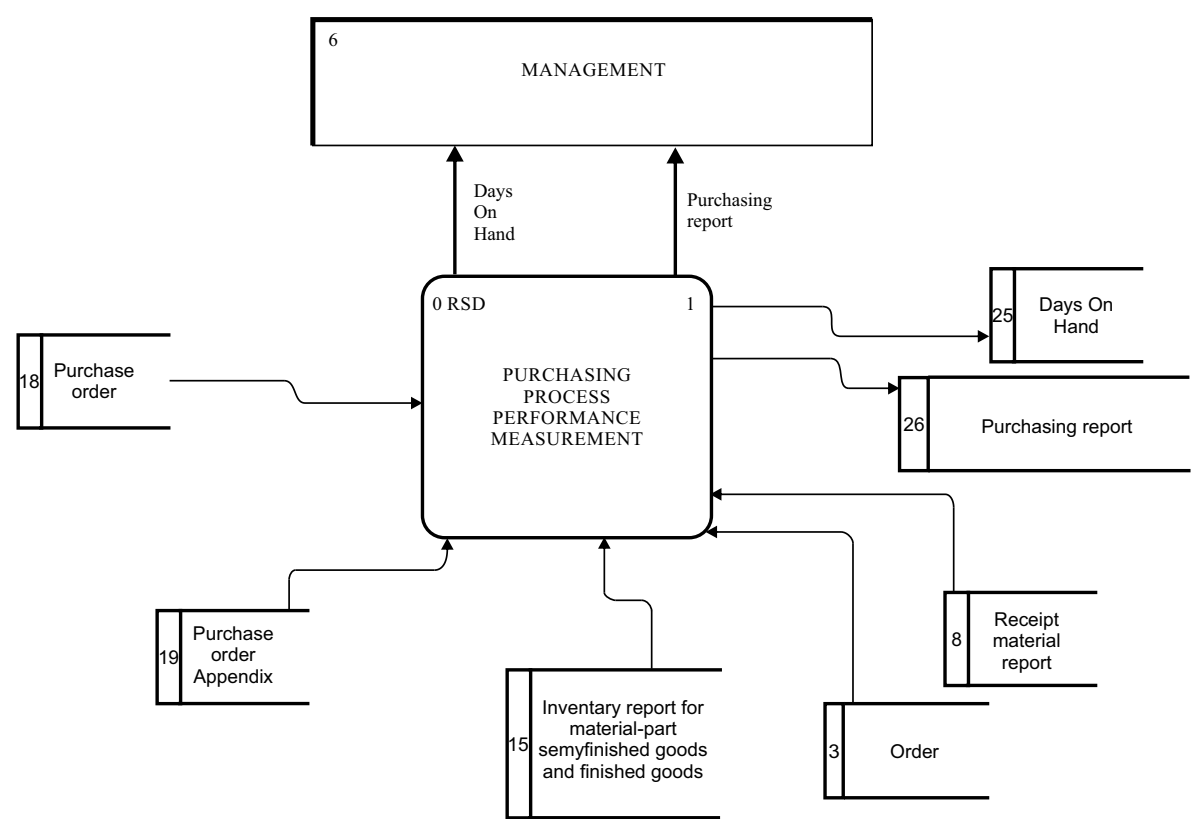

Figure 3 A data flow diagram - The purchasing process performance measurement

Source: Author 


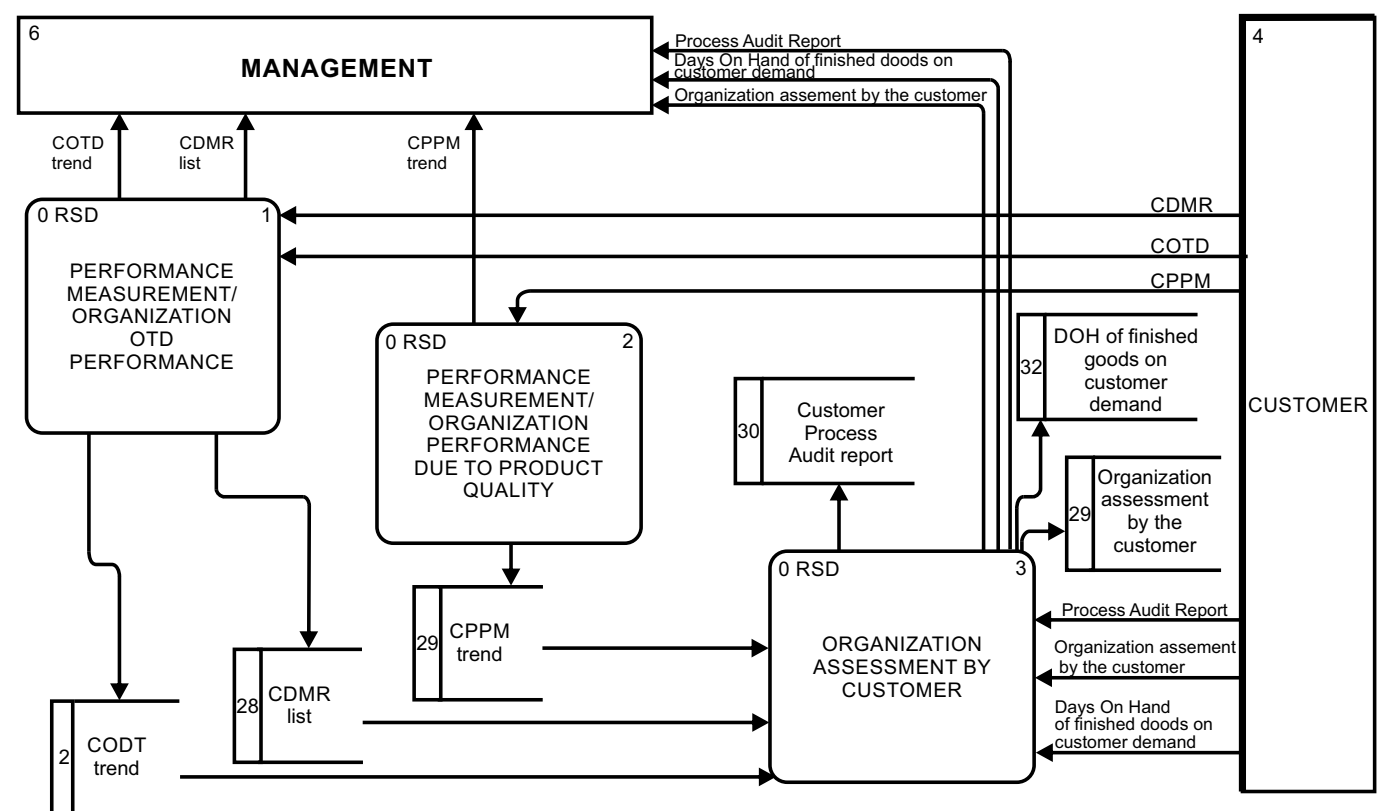

Figure 4 A data flow diagram - The sales process performance measurement

Source: Author

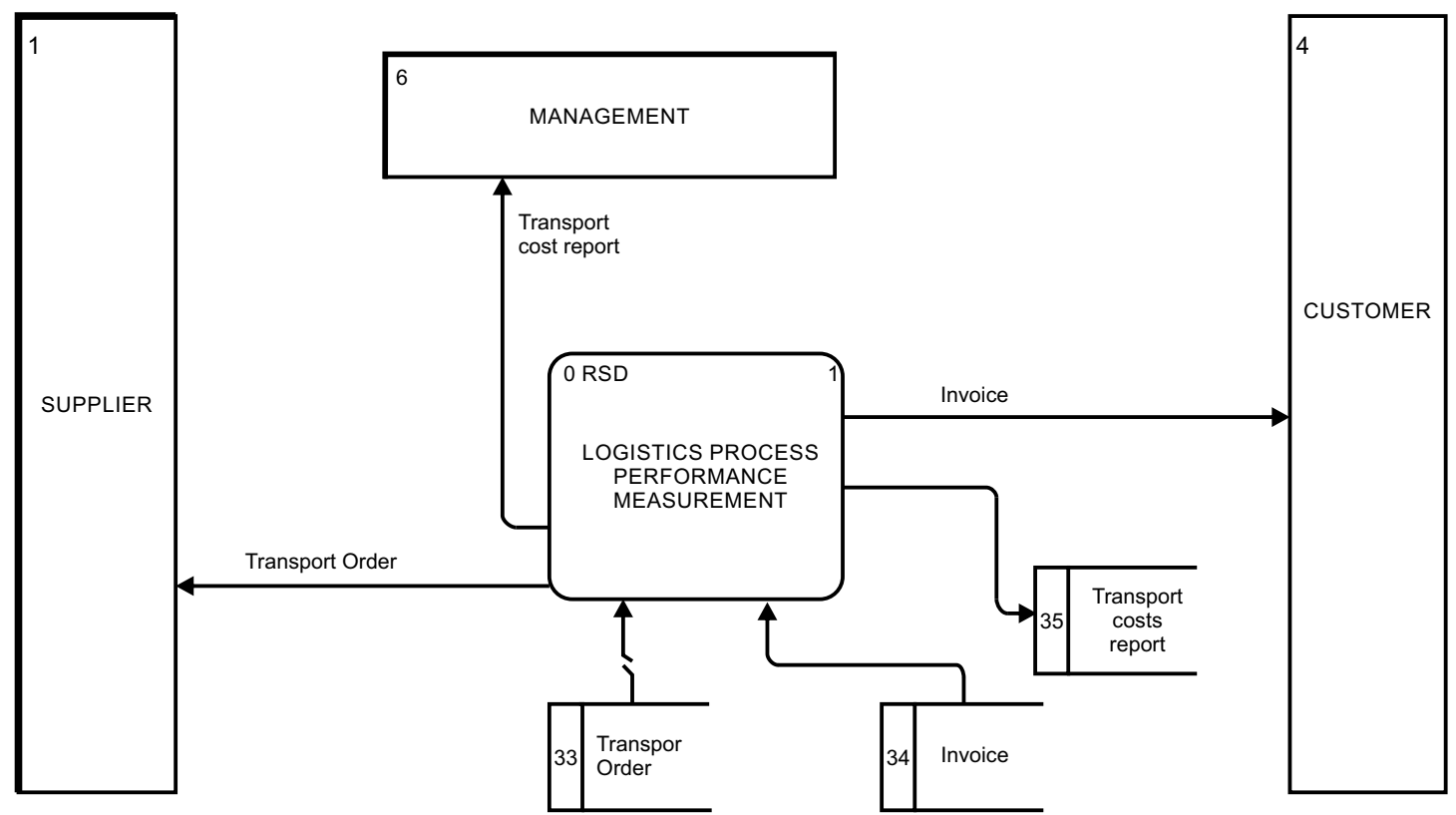

Figure 5 A data flow diagram - The logistics process performance measurement 
- the establishing of the relevant characteristics for each entity type, the properties of such characteristics and the determining of the characteristics of the candidates for the primary key.

The basis for the transformation of the process model into the data model is data flows and data warehouses, which are the fundamental characteristics of the system or the state of the system at various time intervals. In this way, each data flow/ data warehouse is transformed into a data model, which consists of the entities hierarchically related to each other.

On the basis of the identified processes and the process storage in the process modeling in e-supply chains and the key performance indicators and the optimization parameters obtained by using AHP methods, attributes are defined as the key properties for data modeling in e-supply chains.
The logical data model for improving business processes in e-supply chains is made by using the ERwin software tool, as shown in Figure 6.

The developed data model forms the basis for designing a database using the appropriate database management software. The end result is a developed application software prototype, as well as a prototype of Web applications to improve business processes in e-supply chains, which allows all members of a supply chain to gain an insight into the movements of the key performance indicators and the overall supply chain performance through the knowledge of the priority and the weights of the KPI for different types of supply chains and through the monitoring of the target and the current values of the key performance indicators of business processes in different types of supply chains.

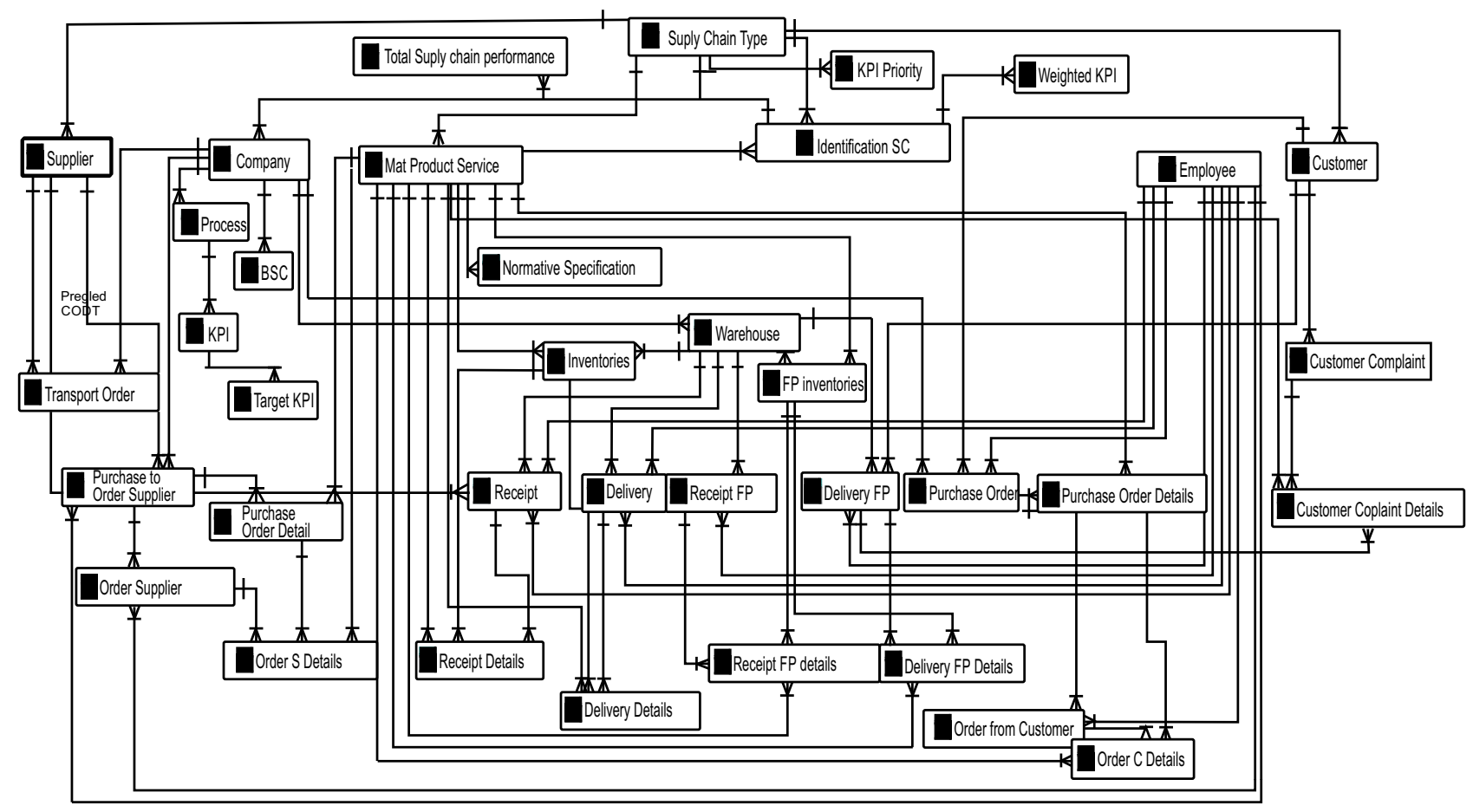

Figure 6 The data model for improving business processes in e-supply chains 


\section{RESEARCH RESULTS}

The developed Web application prototype was tested with the supply chain member organizations in the automotive industry. After the period of the application software testing, a research study was conducted in order to examine the initial hypotheses.

In the context of this study, the influence of the business process modeling and performance on improving the performance of the key business processes in e-supply chains was tested, with the analysis of the impact of the performance improvement of the key business processes on the efficiency and quality of e-supply chains. Also, research was directed towards the examination of the effect of the improvement of the performance of the business processes on the efficiency and quality of supply-chains, as well as the extent to which the application of the developed management information systems for the purpose of improving business processes in the e-supply chain contributes to the greater efficiency and quality of supply chains themselves.

The empirical research was conducted on a sample of production organizations in the Republic of Serbia in the period September - November 2015. The main instrument of this survey was a questionnaire. When compiling the questionnaire, the starting hypotheses were respected. The questionnaire consisted of 52 questions and was exclusively focused on the management of the organization.

For the purpose of confirming the hypotheses, simple and multiple linear regressions were used. Table 4 accounts for the elements to check the initial hypotheses.

Table 4 The elements for the verification of the hypotheses

\begin{tabular}{l|ccccc}
\hline & $\mathrm{R}$ & $\mathrm{R}^{2}$ & Adjusted $\mathrm{R}^{2}$ & $\mathrm{~F}$ & sig \\
\hline $\begin{array}{l}\text { The modeling of business processes and } \\
\text { performance can define the key business } \\
\text { processes in e-supply chains }\end{array}$ & 0.767 & 0.588 & 0.583 & 115.701 & 0.000 \\
$\begin{array}{l}\text { Using Web-based information and } \\
\text { communication solutions can improve the } \\
\text { performance of business processes in e- } \\
\text { supply chains }\end{array}$ & 0.612 & 0.374 & 0.366 & 48.425 & 0.000 \\
$\begin{array}{l}\text { Improving the performance of the key } \\
\text { business processes affects the efficiency } \\
\text { and quality of e-supply chains }\end{array}$ & 0.935 & 0.875 & 0.874 & 567.496 & 0.000 \\
\hline
\end{tabular}

Source: Author

Regression analysis, which, among other things, included the determination of the statistics and measures of the representativeness of the regression models and testing the hypotheses on the significance of the regression relationship, established the statistical significance of the effects of implementing the business process and performance modeling and the application of Web-based information and communication solutions on improving the performance of the key business processes in e-supply chains, as well as the statistical significance of the impact of improving the performance of the key business processes on the efficiency and quality of e-supply chains. 


\section{CONCLUSION}

The developed prototype of the management information system is a system for decision support, which enables the management to identify, structure and solve semi-structured and unstructured problems, and make a choice among different alternatives. By applying the developed information system, the management can quickly and easily obtain information on the key performance indicators for different business processes in different types of supply chains and perform the evaluation and ranking of the supply chains.

In addition, the developed management information system allows the strategic management simulation of a set of the key performance indicators characteristic of the particular type of the supply chain in order to optimize and increase the overall performance of the supply chain. Thus, there is a possibility of simulating different values of each key performance indicator in the set and analyzing its impact on the overall performance of the supply chain. Also, a simulation in parallel with other supply chains is possible in order to achieve the optimal performance of supply chains.

Thus, this system of decision support is aimed at decision making at all levels, but it is of particular importance to higher levels. Through the ability to analyze sensitivity, the system users examine the causality of some alternative routes or examine the consequences that can occur when changing the influencing factors of the selected alternative.

In addition to facilitating the horizontal flow of information, the developed management information system, as a system supportive of decision making, supports vertical information flows, thus helping to integrate the information used at different organizational and management levels of an organization, as well as a number of the organizations that are members of a particular supply chain, enabled by the development of Web-based support to this system.

Interfacing with OEM, customers and suppliers involves an exchange of the displayed indicators and the information accessible via the Web, at users' request, in a pre-agreed form. The application of this model for measuring the performance of business processes in e-supply chains has led to the improvement of business processes along the entire supply chain, because the developed management information system has generated integrated, faithful and transparent metrics and the performance measurement system. This has facilitated the integration of information from different subsystems for strategic decision making and has achieved the automation of strategic planning and forecasting at the level of supply chains.

Given the distinct interdisciplinarity and multidisciplinarity of the research, in accordance with the defined subject matter and purpose of the research, the hypotheses and the chosen research methods, the theoretical-methodological and practical contribution of this research paper reflects in the improvement of the conceptual models of the processes in e-supply chains, developing models for the improvement of the performance of the business processes in e-supply chains and the development of the management information system model to support the key business processes in e-supply chains.

In developing this management information system model, the subject matter of the conducted analysis was no other business processes in the supply chains, which is the limitation of the research. In the context of the above limitation, future research will focus on the analysis of other business processes in the supply chain, so that future developments will mean their integration into the developed model and the Web application in order to improve the performance of supply chains. Also, the existing model will be extended to other key performance indicators, which will achieve that the overall performance of the supply chain, which in this case was dependent on a large number of the key performance indicators, becomes a measure that will even better portray the efficiency and quality of supply chains, and as such will be used for the evaluation and ranking of different types of supply chains.

\section{ACKNOWLEDGMENTS}

The research presented in this paper was supported by the Ministry of Education, Science, and Technological Development of the Republic of Serbia, Grant III-44010. 


\section{REFERENCES}

Arsovski, Z. (2013). Determinants of the implementation of information and communication technologies in clusters of enterprises. Economic horizons, 15(2), 107-123. doi: 10.5937/ ekonhor1302103A

Bai, C., \& Sarkis, J. (2012). Supply chain performancemeasurement system management using neighbourhood rough sets. International Journal of Production Research, 50(9), 2484-2500. doi: 10.1080/00207543.2011.581010

Bai, C., Sarkis, J., Wei, X., \& Koh, L. (2012). Evaluating ecological sustainable performance measures for supply chain management. Supply Chain Management: An International Journal, 17(1), 78-92. doi: $10.1108 / 13598541211212221$

Cabral, I., Grilo, A., \& Cruz-Machado, V. (2012). A decision-making model for lean, agile, resilient and green supply chain management. International Journal of Production Research, 50(17), 4830-4845. doi: 10.1080/00207543.2012.657970

Chan, F. T. S., \& Qi, H. J. (2003). An innovative performance measurement method for supply chain management. Supply chain Management - An International Journal, 8(3), 209-223. doi: $10.1108 / 13598540310484618$

Christopher, M., \& Towill, D. (2000). Supply chain migration from lean and functional to agile and customised. Supply Chain Management - An International Journal, 5(4), 206-213. doi: $10.1108 / 13598540010347334$

Christopher, M., Peck, H., \& Towill, D. (2006). A taxonomy for selecting global supply chain strategies. The International Journal of Logistics Management, 17(2), 277-287. doi:10.1108/09574090610689998

De Toni, A., Nassimbeni, G., \& Tonchia, S. (1994). Service dimensions in the buyer-supplier relationship: A case study. International Journal of Physical Distribution \& Logistics Management, 24(8), 4-14. doi: 10.1108/09600039410071235

Genovese, A., Koh, L. S. C., Kumar, N., \& Tripathi, P. K. (2014). Exploring the challenges in implementing supplier environmental performance measurement models: A case study. Production Planning and Control, 25(13-14), 1198-1211. doi: 10.1080/09537287.2013.808839

Gimenez, C., \& Tachizawa, E. M. (2012). Extending sustainability to suppliers: A systematic literature review. Supply Chain Management - An International Journal, 17(5), 531543. doi:10.1108/13598541211258591

Gunasekaran, A., Patel, C., \& McGaughey, E. (2004). A framework for supply chain performance measurement.
International Journal of Production Economics, 87(3), 333-347. http://dx.doi.org/10.1016/j.ijpe.2003.08.003

Hayes, R. H., \& Wheelwright, S. C. (1984). Restoring our Competitive Advantage. New York, NY: Wiley.

Holmberg, S. (2000). A systems perspective on supply chain measurements. International Journal of Physical Distribution \& Logistics Management, 30(10), 847-868. doi:10.1108/09600030010351246

Karadgi, S. (2014). A Reference Architecture for Real-Time Performance Measurement-An Approach to Monitor and Control Manufacturing Processes. London, UK: Springer.

Koh, L. S. C., Demirbag, M., Bayuraktar, E., Tatoglu, E., \& Zaim, S. (2007). The impact of supply chain management practices on performance of SMEs. Industrial Management \& Data Systems, 107(1), 103-124. doi: 10.1108/02635570710719089

Lambert, D. M. \& Pohlen, R. L. (2001), Supply chain metrics. The International Journal of Logistics Management, 12(1), 1-19, doi: 10.1108/09574090110806190.

Landeghem van, R., \& Persoons, K. (2001). Benchmarking of logistical operations based on a casual model. International Journal of Operations \& Production Management, 21(1-2), 254266. doi: 10.1108/01443570110358576

Mason, J. H., \& Cole, M. H. (2002). Improving electronics manufacturing supply chain agility through outsourcing. International Journal of Physical Distribution \& Logistics Management, 32(7), 610-620. doi: 10.1108/09600030210442612

Morgan, C. (2004). Structure, speed and salience: Performance measurementinthesupplychain. Business Process Management Journal, 10(5), 522-536. doi: 10.1108/14637150410559207

Otto, A., \& Kotzab, H. (2001). Does Supply Chain Management really pay? - Six perspectives to measure the performance of managing a supply chain. European Journal of Operational Research, 144(2), 306-321. doi.org/10.1016/S03772217(02)00396-X

Petroni, A., \& Panciroli, B. (2002). Innovation as a determinant of suppliers' roles and performances: An empirical study in the food machinery industry. European Journal of Purchasing $\mathcal{E}$ Supply Management, 8(3), 135-149. doi.org/10.1016/S09697012(02)00004-7

Robson, I. (2004). From process measurement to performance improvement. Business Process Management Journal, 10(5), 510-521. doi: 10.1108/14637150410559199

Saad, M., \& Patel, B. (2006). An Investigation of supply chain 
performance measurement in the Indian automotive sector. Benchmarking: An International Journal, 13(1-2), 36-53. doi: 10.1108/14635770610644565

Saaty, T. (2010). Economic forecasting with tangible and intagible criteria: The analytic hierarchy process of measurement and its validation. Economic Horizons, 12(1), 5-45.

Shepherd, C., \& Günter, H. (2006). Measuring supply chain performance: Current research and future directions. International Journal of Productivity and Performance
Management, 55(3-4), 242-258. doi: 10.1108/17410400610653219

Tracey, M., \& Tan, C. L. (2001). Empirical analysis of supplier selection and involvement, customer satisfaction, and firm performance. Supply Chain Management - An International Journal, 6(4), 174-188. doi: 10.1108/EUM0000000005709

Vereecke, A., \& Muylle, S. (2006). Performance improvement through supply chain collaboration in Europe. International Journal of Operations \& Production Management, 26(11), 11761198. doi: $10.1108 / 01443570610705818$

Received on $10^{\text {th }}$ November 2016, after revision, accepted for publication on $26^{\text {th }}$ December 2016.

Published online on $30^{\text {th }}$ December 2016.

Dragana Rejman Petrovic is an Assistant Professor at the Faculty of Economics, University of Kragujevac, the Republic of Serbia, where she obtained her PhD degree in the scientific field of statistics and informatics. She teaches the academic subject of Information Systems. The key areas of her research work are business and management information systems, business process management, supply chain management and operational management. 


\title{
UNAPREĐENJE POSLOVNIH PROCESA U E-LANCIMA SNABDEVANJA
}

\author{
Dragana Rejman Petrović* \\ Univerzitet u Kragujevcu, Ekonomski fakultet
}

\begin{abstract}
Razvoj modela za unapređenje poslovnih procesa u e-lancima snabdevanja podrazumeva primenu procesnog pristupa i metodologija za razvoj informacionih sistema, i obuhvata dizajn modela zahteva, logički dizajn modela ključnih procesa sa definisanim tokovima informacija unutar logičkih podsistema, logički dizajn modela podataka, logički dizajn modela mreže i distribucije podataka, kao i logički dizajn modela interface-a za potrebe različitih korisnika. Pri tome korišćene su različite metode i tehnike za različite faze razvoja menadžment informacionog sistema, upravljanje poslovnim procesima, upravljanje performansama poslovnih procesa $\mathrm{i}$ analitički hijerarhijski proces kao metod višekriterijumskog odlučivanja. $U$ radu su analizirani poslovni procesi i različiti tipovi lanaca snabdevanja u automobilskoj industriji kao predstavniku složenih sistema. Izabrani su ključni poslovni procesi i ključni indikatori performansi poslovnih procesa na bazi kojih je razvijen model analitičkog hijerarhijskog procesa i vršena njihova optimizacija. Rezultat rada je model menadžment informacionog sistema za unapređenje ključnih poslovnih procesa u e-lancima snabdevanja. Rezultati istraživanja pokazuju da se kroz unapređenje performansi poslovnih procesa u e-lancima snabdevanja, primenu razvijenog modela za unapređenje ključnih poslovnih procesa, kao i primenu Web baziranih informaciono-komunikacionih rešenja utiče na efikasnost i kvalitet e-lanaca snabdevanja.
\end{abstract}

Ključne reči: lanci snabdevanja, poslovni procesi, merenje performansi, menadžment informacioni sistemi

JEL Classification: M10, M15, M21

\section{UVOD}

Fokus lanaca snabdevanja više nije samo na specifičnim funkcijama $\mathrm{u}$ organizacijama poput nabavke, proizvodnje i isporuke, već i na unapredjenju performansi sistema $u$ internom $i$ eksternom okruženju. U konkurentskom okruženju XXI-og veka, od organizacija u lancu snabdevanja zahteva

\footnotetext{
* Korespondencija: D. Rejman Petrović, Univerzitet u Kragujevcu, Ekonomski fakultet, $Đ$. Pucara 3, 34000 Kragujevac, Republika Srbija; e-mail: rejman@kg.ac.rs
}

se da obezbede efikasnost, visok nivo usluge, brz odziv i visok kvalitet proizvoda i usluga. Upravljanje lancima snabdevanja pretpostavlja holistički i strategijski pristup procesima tražnje, proizvodnje, nabavke i logistike. Koncept lanaca snabdevanja je suštinski izmenio prirodu organizacije. Kontrola se više ne zasniva na direktnoj kontroli poslovnih procesa individualnih organizacija, već na kontroli svih procesa između integrisanih organizacija kao članica lanaca snabdevanja. Koordinacija između organizacija u lancu snabdevanja predstavlja ključ 
njegovog efikasnog sprovođenja. Neophodno je da organizacije postanu svesne svojih uloga i aktivnosti u lancu snabdevanja i činjenice da njihove performanse utiču i na performanse drugih članica $u$ lancu snabdevanja. To znači da organizacije moraju upravljati performansama lanca snabdevanja kako bi postigle konkurentsku prednost.

U okviru ovog rada prikazan je razvijeni model merenja performansi ključnih poslovnih procesa $u$ e-lancima snabdevanja koji omogućava poboljšanje efikasnosti i kvaliteta celokupnog lanca snabdevanja. U kreiranju razvijenog modela merenja performansi ključnih poslovnih procesa u e-lancima snabdevanja pošlo se od koncepta upravljanja kvalitetom $\mathrm{u}$ lancima snabdevanja. Proces upravljanja kvalitetom lanaca snabdevanja podrazumeva merenje, analizu i stalno poboljšanje proizvoda, usluga i poslovnih procesa, kao i koordinaciju i integraciju poslovnih procesa svih organizacija članica lanca snabdevanja.

Razvijeni model merenja performansi omogućava strukturirani pristup kvalitetu u lancima snabdevanja, koji podrazumeva i zahtevani i definisani nivo kvaliteta dizajna mreže lanaca, kvalitet procesa nabavke, prodaje i logistike i upotrebu sistema za planiranje resursa organizacije. Kvalitet i efikasnost svakog pojedinačnog poslovnog procesa meri se prema analiziranim, izabranim i definisanim ključnim indikatorima performansi koji imaju različit relativni značaj za različite tipove lanaca snabdevanja.

Razvijeni model je testiran na organizacijama članicama lanaca snabdevanja $\mathrm{u}$ automobilskoj industriji i obuhvatio je sekvencu organizacija dobavljač - kupac, koja se ponavlja u okviru celog lanca snabdevanja, jer svaka organizacija u lancu snabdevanja ima svoje dobavljače i svoje kupce. Polazeći od navedenih činjenica i pretpostavki razvijeni model postaje primenljiv za svaku članicu lanca snabdevanja.

U novom pristupu, akcenat je stavljen na izračunavanje ključih indikatora performansi, identifikovanje gepova u zavisnosti od ostvarenih i ciljnih vrednosti ključih indikatora performansi koji pripadaju određenom atributu mera (kvalitet - $Q$, troškovi - C, isporuka D i fleksibilnost - F), kao i na izračunavanje ukupne performanse različitih tipova lanaca snabdevanja (efikasan, lean, brz i hibridni), koja je rezultat integrisanih ključnih indikatora performansi i njihove relativne važnosti u odnosu na pojedini tip lanca snabdevanja. Zapravo, ocenjujući sve ključne poslovne procese u lancu snabdevanja pomoću izabranih i definisanih ključnih indikatora performansi i njihovog različitog prioriteta, dolazi se do ukupne mere performansi lanca snabdevanja. Ovakav pristup omogućava menadžmentu, kako na nivou sekvence dobavljač - organizacija - kupac, tako i na nivou proizvođača originalne opreme (Original Equipment Manufacturer - OEM), kao vlasnika lanca snabdevanja, praćenje, analizu i uočavanje kritičnih mesta i karika u lancu snabdevanja, kao i različite simulacije s tim u vezi, a $u$ cilju unapređenja poslovnih procesa u e-lancima snabdevanja.

Predmet istraživanja $u$ radu su poslovni procesi $u$ e-lancima snabdevanja i načini za njihovo unapređenje, kao i unapređenje celokupne mreže poslovnih procesa.

Cilj rada je razvoj modela za unapređenje performansi e-lanaca snabdevanja kroz unapređenje performansi ključnih poslovnih procesa, uz podršku informacionokomunikacionih rešenja.

Shodno opredeljenom predmetu i cilju istraživanja, $u$ radu su postavljene sledeće hipoteze:

H1: Modeliranjem poslovnih procesa i performansi, mogu se definisati ključni poslovni procesi u e-lancima snabdevanja.

H2: Primenom Web baziranih informacionokomunikacionih rešenja mogu se unaprediti performanse poslovnih procesa $\mathrm{u}$ e-lancima snabdevanja.

H3: Unapređenje performansi ključnih poslovnih procesa utiče na efikasnost i kvalitet e-lanaca snabdevanja.

Za razvoj modela menadžment informacionog sistema za merenje performansi poslovnih procesa u e-lancima snabdevanja, korišćeni su metodi koji podržavaju pojedine ili više faza životnog ciklusa razvoja informacionih sistema kao što su: metodologija životnog ciklusa razvoja informacionih sistema (System Development Life Cycle - SDLC), metod za planiranje poslovnih sistema (Business System 
Planning - BSP), metod strukturirane analize sistema za funkcionalno modeliranje funkcija i procesa sistema (Structured Systems Analysis - SSA), metod strukturirane sistemske analize i dizajna aplikacija (Structured Systems Analysis and Design Method SSADM), metod objektno orijentisane analize za identifikaciju, opis objekata i specifikaciju ključnih atributa unutar objekata i interakcija između objekata, dijagram dekompozicije procesa kao sredstvo $u$ modeliranju procesa $u$ fazi analize i prikazivanju osnovnih logičkih interakcija između procesa (Object Oriented Analysis - OOA), tehnika za grafičko predstavljanje logičkog modela sistema u fazi analize i dizajna razvoja informacionog sistema (Data Flow Diagram - DFD), logičko modeliranje podataka pomoću modela zavisnosti entiteta (Entity Relationship Model ERM). Za evaluaciju i rangiranje lanaca snabdevanja primenjen je metod višekriterijumskog odlučivanja, AHP (Analytic Hierarchy Process - AHP). Na ovaj način, ostvarilo se unapređenje modela podataka sa aspekta zahteva primenjenog AHP modela.

Rad se sastoji od pet sekcija. Posle Uvoda, ukazano je na značaj merenja performansi poslovnih procesa u lancima snabdevanja i vezu između prioriteta različitih tipovi mera performansi i određenog tipa lanca snabdevanja. U trećoj sekciji je predstavljeno planiranje i razvoj informacionog sistema za podršku i unapređenje poslovnih procesa $u$ e-lancima snabdevanja. U četvrtoj sekciji su navedeni ključni rezultati sprovedenog istraživanja. Peta sekcija sumira zaključke, ukazuje na teorijskometodološki i praktični doprinos rada i definiše moguće pravce daljih istraživanja.

\section{MERENJE PERFORMANSI POSLOVNIH PROCESA U LANCIMA SNABDEVANJA}

Sa povećanjem broja input-a, kao i sa povećanjem obima kontrole i većom složenošću operacija, upravljanje podacima (Data Management - DM), kao i njihovo korišćenje postaje kompleksnije. Događaji proizvode podatke i svaki podatak je potencijalni pokazatelj, a samo su neki pokazatelji ključni indikatori performansi (Key Performance Indicators - KPI) (Karadgi, 2014).
Svi članovi lanca snabdevanja, uzvodno i nizvodno, su učesnici koji imaju uticaja na performanse lanca snabdevanja (na primer, kvalitet, isporuku, cenu, fleksibilnost). Potreba da se odredi odgovarajući tip mera performansi lanca snabdevanja je od vitalnog značaja, jer će kao takav da utiče na donošenje odluka. Na primer, ako mera ne obezbedi tačne i relevantne informacije o procesu koji se meri, to može prouzrokovati pogrešne odluke praćene kontraproduktivnim akcijama. Mnoga realizovana istraživanja naglašavaju potrebu za pravim tipom mera performansi u lancima snabdevanja (Otto \& Kotzab, 2001; Shepherd \& Günter, 2006; Vereecke \& Muylle, 2006; Koh, Demirbag, Bayuraktar, Tatoglu, \& Zaim, 2007; Bai \& Sarkis, 2012; Bai, Sarkis, Wei \& Koh, 2012; Cabral, Grilo \& Cruz-Machado, 2012; Gimenez \& Tachizawa, 2012; Genovese, Lenny Koh, Kumar \& Tripathi, 2014). Rezultati dobijeni kroz navedena istraživanja ukazuju na izabrane, definisane i testirane različite mere performansi koje koriste organizacije.

Oblast performansi u lancima snabdevanja je široko pokrivena u literaturi (Holmberg, 2000; Lambert \& Pohlen, 2001; Landeghem van \& Persoons, 2001; Tracey \& Tan, 2001; Petroni \& d Panciroli, 2002; Chan \& Qi, 2003; Gunasekaran, Patel \& McGaughey, 2004; Morgan, 2004). Navedene studije ističu potrebu merenja efikasnosti integrisanog lanca snabdevanja.

A. Petroni i B. Panciroli (2002) tvrde da kupci obično zadržavaju dobavljače koji postižu najviši ukupni rezultat koji je iskazan kroz cene, kvalitet, fleksibilnost proizvodnje i vremena isporuke. A. De Toni, G. Nassimbeni i S. Tonchia (1994) tvrde da efikasno kvalitetan lanac snabdevanja zavisi od postizanja visokog nivoa performansi u pogledu troškova, kvaliteta i ukupnog vremena da se proizvod osmisli i pojavi na tržištu. R. H. Hayes i S. C. Wheelwright (1984) su bili prvi koji su predstavili metode za ostvarivanje operativne strategije pomoću četiri dimenzija koje organizacija bira kada se takmiči u okviru ciljnog tržišta, kao što su kvalitet, cena, fleksibilnost i isporuka. Njihova originalna formulacija je bila primenljiva na sve funkcije.

D. M. Lambert i R. L. Pohlen (2001) tvrde da kvalitetno osmišljen sistem merenja u lancu snabdevanja može da dovede do konkurentne prednosti kroz diferenciranje 
usluga i niže troškove. Oni, takođe, smatraju da implementacija strategije lanca snabdevanja zahteva metriku koja usklađuje performanse sa ciljevima drugih članica lanca snabdevanja. Performanse lanca snabdevanja mogu da se posmatraju kao sistem mera, kao što su kvalitet, isporuka, fleksibilnost i troškovi/cena. Tradicionalne mere performansi, kao što je profitabilnost, su manje relevantne za merenje performansi lanca snabdevanja.

Uspostavljanje sistema merenja zahteva znanje o procesima u organizaciji, i između kupaca i dobavljača. Da bi se generisalo ovo znanje organizacija mora da odluči koje mere performansi će meriti. I. Robson (2004) navodi „bez znanja tačnih okolnosti pod kojima će sistem merenja dovesti ili neće dovesti do poboljšanja performansi, teško je opravdati dodatne troškove implementacije sistema merenja“.

Sistem merenja performansi lanca snabdevanja sastoji se od skupa parametara koji mogu u potpunosti da opišu performanse logistike i proizvodnje celokupnog lanca sanbdevanja, kako iz perspektive krajnjih kupaca, tako i svakog drugog člana u lancu snabdevanja. Međutim, postoji nekoliko mera performansi i metrike u lancu snabdevanja koje se mogu ocenjivati. Najčešće korišćene u praksi, ali i najviše citirane $u$ istraživanjima su sledeći atributi mera: kvalitet, isporuka, troškovi/ cena i fleksibilnost.

S obzirom na to da postoje različiti tipovi lanaca snabdevanja, kao i da lanci snabdevanja imaju različite karakteristike, kao takvi zahtevaju da im se pojedinačno posveti pažnja, kako bi se postigle optimalne performanse lanca snabdevanja (Christopher \& Towill, 2000; Mason \& Cole, 2002; Saad \& Patel 2006; Christopher, Peck \& Towill, 2006). Određene mere performansi $u$ lancu snabdevanja će biti prioritet $\mathrm{u}$ zavisnosti od tipa lanca snabdevanja.

Za efikasan lanac snabdevanja primarna mera performansi su troškovi, na primer, ukupni troškovi od dobavljača preko internog lanca snabdevanja do kupca, odnosno sve vrste troškova koje imaju uticaja na troškove proizvodnje. Agilan lanac snabdevanja koji brzo reaguje na zahteve tržišta ima kraći lead time,tako da je kod ove vrste lanaca snabdevanja primarna mera isporuka, ali i fleksibilnost (mix) proizvodnje i kvalitet proizvoda. Kraći lead time od narudžbine do isporuke je još jedna važna mera za lean lanac snabdevanja. Hibridni lanac snabdevanja se fokusira na skraćivanje vremena, ali bez stvaranja dodatnih troškova, a u cilju prilagođavanja zahtevima kupaca, tako da su primarne mere performansi: isporuka, fleksibilnost i kvalitet.

Na ovaj način je uspostavljena veza između prioriteta različitih tipova mera performansi u lancu snabdevanja i određenog tipa lanca snabdevanja, što je predstavljalo osnovu za razvoj modela za unapređenje performansi poslovnih procesa u e-lancima snabdevanja.

\section{PLANIRANJE I RAZVOJ \\ INFORMACIONOG SISTEMA ZA PODRŠKU I UNAPREĐENJE POSLOVNIH PROCESA U E-LANCIMA SNABDEVANJA}

U procesu planiranja i razvoja informacionog sistema za podršku i unapređenje poslovnih procesa u e-lancima snabdevanja korišćeni su metod za planiranje poslovnih sistema (Business System Planning - BSP), strukturirana sistem analiza (Structured System Analysis - SSA), sistemi za upravljanje bazama podataka (Data Base Mangement Systems - DBMS) (Arsovski, 2013) i analitički hijerarhijski proces (Analytic Hierarchy Process - AHP) kao metod višekriterijumskog odlučivanja (Saaty, 2010).

Pomoću BSP metoda, a na osnovu zahteva i potreba stakeholder-a za unapređenja performansi poslovnih procesa u e-lancima snabdeavanja, ostvareno je sledeće:

- razvijeni su modeli ciljeva poslovanja organizacije i lanaca snabdevanja, kao i ciljevi informacionog sistema za unapređenje performansi poslovnih procesa u e-lancima snabdevanja,

- identifikovani su ključni poslovni procesi koji egzistiraju u organizaciji i lancima snabdevanja, procedure i uputstva kojima se propisuje način izvođenja procesa i aktivnosti, nadležnosti i odgovornosti, termini, dokumentacija, standardi, izveštaji za različite nivoe upravljanja i odlučivanja, resursi i dr. 
- razvijen je generički logički model ključnih procesa i podataka za podršku informacionog sistema za unapređenje performansi poslovnih procesa $\mathrm{u}$ e-lancima snabdevanja.

Pomoću SSA metoda, korišćenjem softverskih alata ERwin i BPwin, razvijeni su detaljan logički model procesa, detaljan logički model podataka, i model interface-a.

Pomoću sistema za upravljanje bazama podataka izvršena je transformacija logičkog modela podataka $\mathrm{u}$ bazu podataka i na taj način je postignuta konzistentnost podataka, eliminisana redundantnost podataka i obezbeđen sistem zaštite podataka od neovlašćenog pristupa.

Pomoću AHP metoda razvijen je model za evaluaciju lanaca snabdevanja i njihovo rangiranje prema odabranim kriterijumima, kako bi se na osnovu performanse lanca snabdevanja, sagledao rang lanaca snabdevanja i odlučilo gde je potrebno reagovati u cilju unapređenja njegovih performansi.

\section{Model zahteva stakeholder-a za upravljanje performansama poslovnih procesa u e-lancima snabdevanja}

Za razvoj modela menadžment informacionog sistema za merenje i unapređenje performansi poslovnih procesa u e-lancima snabdevanja, prvo su definisati zahtevi zainteresovanih korisnika za unapređenje performansi poslovnih procesa u e-lancima snabdevanja.

Dizajniranje modela zahteva predstavlja osnovu za definisanje pristupa i strategije razvoja informacionog sistema, tako da je u tom procesu prikupljanje zahteva i upoznavanje sa potrebama korisnika važna aktivnost. Postupak modeliranja zahteva obuhvata analizu različitih vrsta zahteva stakeholder-a.

Postupak analize i evidencije zahteva podrazumevao je identifikovanje svih zahteva koji su u funkciji unapređenja ključnih procesa u lancima snabdevanja i koji na bilo koji način utiču na budući sistem ili na koje će budući sistem uticati. S obzirom na to da se zahtevi različitih stakeholder-a razlikuju, neophodno je napraviti njihovu kategorizaciju.
Stakeholder-i mogu biti interni i eksterni. Interni stakeholder-i su menadžeri, zaposleni i vlasnici organizacije. Eksterni stakeholder-i su OEM, kupci, dobavljači, poslovni partneri, banke, ali i društvena zajednica, državni organi, razne nevladine organizacije itd.

Za definisanje i analizu zahteva stakeholder-a korišćene su tehnike intervjua, analize rada $\mathrm{u}$ konkretnom okruženju i proučavanja dokumentacije. U cilju izrade modela zahteva izabrani su sledeći stakeholder-i: menadžment, vlasnici, dobavljači, kupci i OEM.

Zahtevi i potrebe menadžmenta organizacije sa aspekta unapređenja performansi poslovnih procesa u e-lancima snabdevanja, odnose se na efikasnost informacionog sistema $u$ pogledu automatskog $i$ efikasnog generisanja različitih tipova izveštaja o ključnim indikatorima performansi za različite poslovne procese. Takođe, menadžment ima potrebe i zahteve za upotrebom metoda za višekriterijumsku analizu i optimizaciju, u ovom slučaju AHP modela, s obzirom da su menadžerske odluke veoma kompleksne i najčešće obuhvataju više suprotstavljenih kriterijuma. To omogućava menadžmentu da kod složenih problema sa većim brojem kriterijuma i alternativa relativno lako uspostavi relacije između uticajnih faktora, prepozna njihov eksplicitni ili relativni uticaj i značaj u realnim uslovima, i odredi dominantnost jednog faktora u odnosu na drugi. Zahtevi i potrebe menadžmenta su formulisani kao mogućnost:

- praćenja ključnih poslovnih procesa, u ovom slučaju nabavke, prodaje i logistike,

- merenja i analize njihovih ključnih indikatora performansi u različitim vremenskim intervalima,

- merenja i analize ukupne performanse različitih tipova lanca snabdevanja u različitim vremenskim intervalima i

- evaluacije, rangiranja i upoređivanja različitih tipova lanaca snabdevanja.

Za vlasnike su izabrani zahtevi i potrebe za informacijama koji se odnose na visinu dobiti na uloženi kapital i dugoročno održivo uvećanje kapitala, procenata rasta prodaje, procenata smanjenja ili povećanja troškova transporta i optimizacije lanca snabdevanja. 
Za dobavljača su izabrani zahtevi i potrebe koji se odnose na:

- definisane specifikacije isporuka proizvoda/usluga,

- elektronsku razmena podataka, odnosno, prijem EDI (Electronic Data Interchage - EDI) porudžbina,

- mogućnost predviđanja za period od šest meseci,

- razmenu informacija o ostvarenim ključnim indikatorima performansi poslovnim procesima i njihovim ciljnim vrednostima,

- informacije o ponderima o ključnim indikatorima performansi za odgovarajući tip lanca snabdevanja.

Za kupce su izabrani zahtevi i potrebe koji se odnose na: informacije $\mathrm{u}$ vezi nivoa kvaliteta proizvoda, usaglašenost kvaliteta isporuke, poštovanje rokova, prihvatljivost cene proizvoda, odnos kvalitet i cene, raspoloživost potrebnih količina proizvoda/ broj pruženih usluga, dostupnost informacija o proizvodima/uslugama, dostupnost informacija o stanju porudžbina, način postupanja sa reklamacijama, razmenu inforamcija o ostvareni ključnim indikatorima performansi poslovnih procesa i njihovim ciljnim vrednostima i informacije o ponderima ključnim indikatorima performansi za odgovarajući tip lanca snabdevanja. Kupci svoje zahteve artikulišu preko skraćenice 100/0/30, što znači da organizacija, kao dobavljač, mora obezbediti $100 \%$ isporuke na vreme, sa 0 ppm (parts per milion - bez delova lošeg kvaliteta), najkasnije 30 dana po lansiranju proizvodnje. Da bi to ostvarila, organizacija ovako definisane zahteve mora isto zahtevati od svojih dobavljača, kako bi ispunila zahteve kupaca.

Za OEM, kao vlasnika lanca snabdevanja, su izabrani zahtevi i potrebe koji se odnose na pristup informacijama o zahtevanim ključnim indikatorima performansi svih organizacija članica lanca snabdevanja u definisanoj formi.

Model zahteva stakeholder-a za upravljanje performansama poslovnih procesa $u$ e-lancima snabdevanja prikazan je na Slici 1.

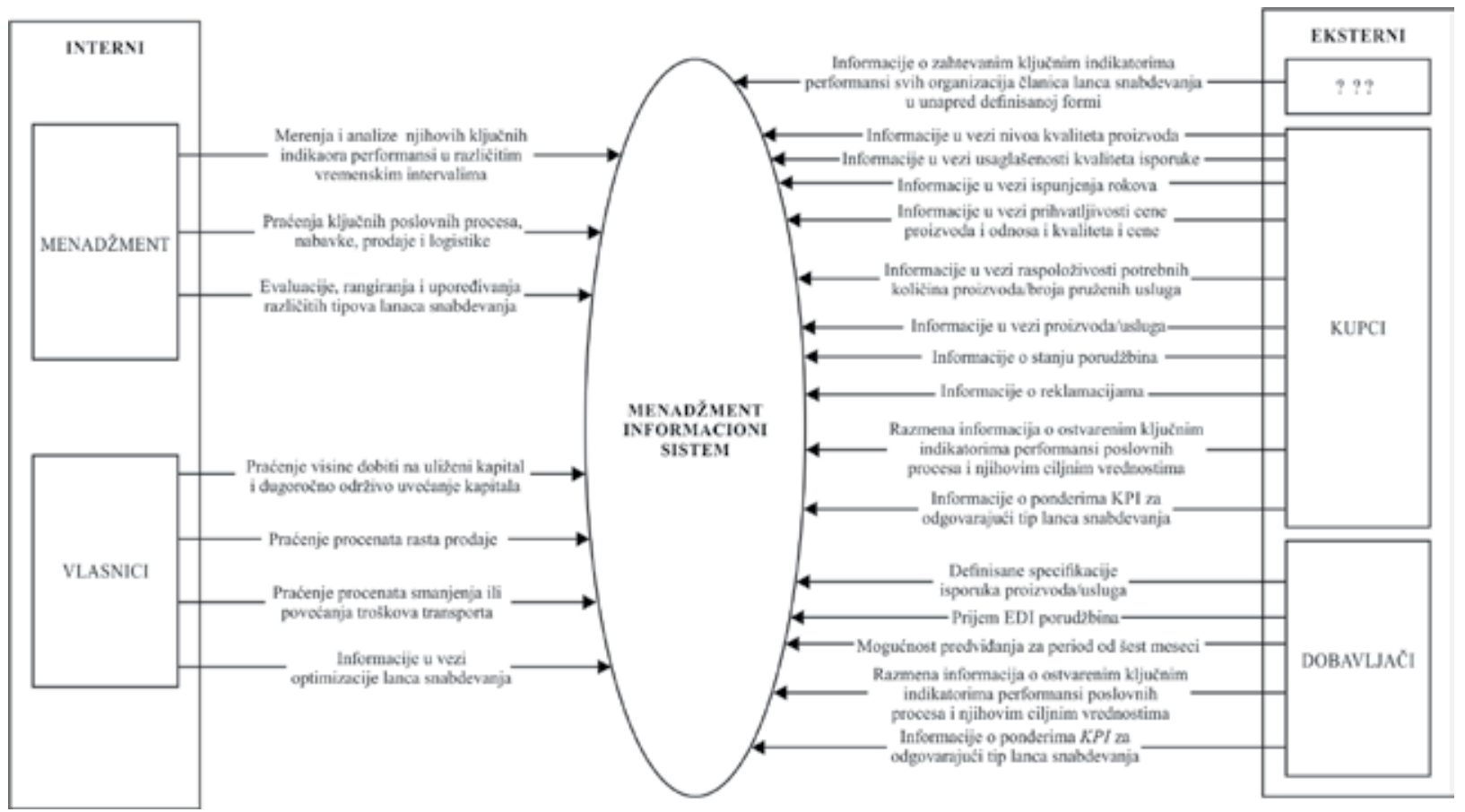

Slika 1 Model zahteva stakeholder-a za upravljanje performansama poslovnih procesa u e-lancima snabdevanja Izvor: Autor 
Analiza zahteva korisnika izvršena je za sva tri nivoa menadžmenta - strategijski, taktički i operativni. Na osnovu specifikacije zahteva za informacijama na svim nivoima upravljanja izvršena je sistematizacija i specifikacija informacioniih potreba po poslovnim procesima, na osnovu čega je izvršeno i modeliranje interface-a za potrebe menadžmenta. S obzirom na različite karakteristike zadataka i različite informacije za svaki nivo upravljanja, definisanje i analiza zahteva korisnika zasnivala se na činjenici da različiti nivoi upravljanja i odlučivanja postavljaju specifične zahteve $u$ pogledu obima i vrste informacija koje im treba obezbediti. Različitost se odnosi na potrebne pokazatelje i informacije, period dostavljanja potrebnih informacija, i formu dostavljanja informacija (Tabela 1).

Tabela 1 Sistematizacija i specifikacija informacionih potreba po poslovnim procesima

\begin{tabular}{|c|c|c|c|c|}
\hline$\stackrel{\circ}{\stackrel{2}{z}}$ & Procesi & Pokazatelji & Period & Forma \\
\hline 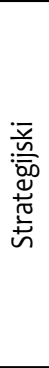 & $\begin{array}{l}\text { Lanac } \\
\text { snabdevanja } \\
\text { Nabavka } \\
\text { Prodaja } \\
\text { Logistika }\end{array}$ & $\begin{array}{l}\text { Ukupna ocena identifikovanih tipova lanaca snabdevanja } \\
\text { Rang različitih tipova lanaca snabdevanja } \\
\text { Prioriteti KPI-a po tipovima lanaca snabdevanja } \\
\text { Uticaj promene relativne važnosti različitih kriterijuma na rang lanaca snabdevanja } \\
\text { Uticaj promene prioriteta pojedinačnih KPI na rang lanaca snabdevanja } \\
\text { Evaluacija i rangiranje dobavljača u zavisnosti od tipa lanca snabdevanja } \\
\text { \% troškova nabavke od čistog prihoda od prodaje (ČPP) } \\
\text { Rast prodaje } \\
\text { \% troškova transporta od čistog prihoda od prodaje }\end{array}$ & $\begin{array}{l}\text { Petogodišnje, } \\
\text { godišnje i } \\
\text { kvartalno }\end{array}$ & 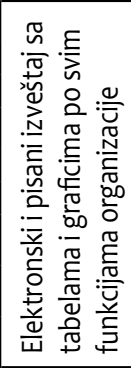 \\
\hline 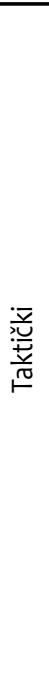 & $\begin{array}{l}\text { Nabavka } \\
\text { Prodaja }\end{array}$ & $\begin{array}{l}\text { Troškovi nabavke } \\
\text { Nabavka po dobavljačima } \\
\text { Reklamacije prema dobavljačima } \\
\text { OTD dobavljača (Isporuka na vreme) } \\
\text { PPM dobavljača (Udeo neusaglašenih delova na milion proizvedenih) } \\
\text { DMR dobavljača (Reklamacije iz reklamacionog zapisnika) } \\
\text { Troškovi lošeg kvaliteta dobavljača } \\
\text { Ocena dobavljača } \\
\text { Ostvarena prodaja } \\
\text { Prodaja po kupcima } \\
\text { Reklamacije od kupaca } \\
\text { OTD (Isporuka na vreme) } \\
\text { PPM (Udeo neusaglašenih delova na milion proizvedenih) } \\
\text { DMR (Reklamacije iz reklamacionog zapisnika) } \\
\text { Troškovi lošeg kvaliteta } \\
\text { Ocena organiazcije od strane kupca } \\
\text { Ukupni troškovi transporta } \\
\text { Redovni i vanredni troškovi transporta } \\
\text { Troškovi transporta po svakom pružaocu usluge } \\
\text { Reklamacije po uslugama } \\
\text { Ocena pružalaca usluga }\end{array}$ & $\begin{array}{l}\text { Kvartalno i } \\
\text { mesečno }\end{array}$ & 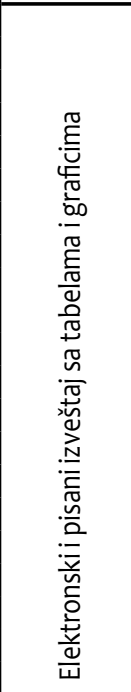 \\
\hline 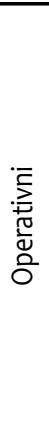 & Nabavka & $\begin{array}{l}\text { OTD dobavljača (Isporuka na vreme) } \\
\text { PPM dobavljača (Udeo neusaglašenih delova na milion proizvedenih) } \\
\text { DMR dobavljača (Reklamacije iz reklamacionog zapisnika) } \\
\text { Troškovi lošeg kvaliteta dobavljača } \\
\text { OTD (Isporuka na vreme) } \\
\text { PPM (Udeo neusaglašenih delova na milion proizvedenih) } \\
\text { DMR (Reklamacije iz reklamacionog zapisnika) } \\
\text { Troškovi lošeg kvaliteta } \\
\text { Ukupni troškovi transporta } \\
\text { Troškovi transporta inbound redovni } \\
\text { Troškovi transporta inbound vanredni } \\
\text { Troškovi transporta outbound redovni } \\
\text { Troškovi transporta outbound vanredni }\end{array}$ & $\begin{array}{l}\text { Nedeljno } \\
\text { i dnevno }\end{array}$ & 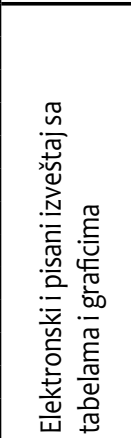 \\
\hline
\end{tabular}

Izvor: Autor 
Pored uobičajenih i $\mathrm{u}$ praksi veoma rasprostranjenih zahteva menadžmenta, postoji tendencija za novim zahtevima menadžmenta u vezi evaluacije i rangiranja lanaca snabdevanja, tako da su i oni pridruženi i integrisani u razvijeni i predstavljeni model za unapređenja poslovnih proces u e-lancima snabdevanja, što predstavlja iskorak ovog menadžment informacionog sistema.

\section{Modeliranje procesa u e-lancima snabdevanja}

Za planiranje i razvoj informacionog sistema, ključna faza je analiza, izbor ključnih procesa i definisanje procesa poslovanja. U zavisnosti od toga koliko su precizno izabrani i definisani procesi poslovanja zavisi i kvalitet projektovanog informacionog sistema. Kako bi informacioni sistem bio nezavisan od budućih organizacionih promena poslovnog sistema, neophodno je da se isti bazira na procese, umesto na organizacione celine, tj. funkcije poslovnog sistema. Pored toga, procesi omogućavaju bolje razumevanje i olakšavaju analizu funkcionisanja poslovnog sistema.

Za modeliranje poslovnih procesa $\mathrm{u}$ e-lancima snabdevanja treba razmatrati lanac snabdevanja $u$ celini, koji predstavlja integraciju veoma velikih i kompleksnih multidisciplinarno zavisnih procesa $\mathrm{i}$ informacija. Procesi $\mathrm{u}$ lancu snabdevanja $\mathrm{u}$ automobilskoj industriji počinju nabavkom resursa i realizuju se preko procesa proizvodnje, montaže, skladištenja, transporta, i završavaju se sa isporukom gotovog proizvoda do krajnjeg kupca.

U skladu sa predmetom istraživanja za potrebe ovog rada, koji se odnosi na poslovne procese u e-lancima snabdevanja i utvrđivanje načina za unapređenje mreže poslovnih procesa i razvoja modela za unapređenje performansi poslovnih procesa $\mathrm{u}$ e-lancima snabdevanja, analizirani su lanci snabdevanja organizacija $\mathrm{u}$ automobilskoj industriji koje pripadaju nivou Tier 3.

Imajući u vidu definisane i utvrđene izabrane ključne indikatore performansi, osnovu za definisanje strukture menadžment informacionog sistema za unapređenje performansi poslovnih procesa $\mathrm{u}$ e-lancima snabdevanja čine procesi: nabavka, prodaja i logistika. U okviru svakog modula definisani su podsistemi za merenje performansi, koji omogućavaju menadžmentu organizacije da pristupi informacijama o ostvarenim ključnim indikatorima performansi za svaki poslovni proces. Moduli se mogu primenjivati pojedinačno, ali prava snaga informacionog sistema za merenje performansi poslovnih procesa $\mathrm{u}$ e-lancima snabdevanja leži $u$ sinergiji integrisanih modula, jer se na taj način omogućava integrisano merenje performansi lanca snabdevanja.

Osnovni zadatak procesa nabavke je ostvarivanje sedam glavnih ciljeva: pravi proizvod/usluga, $\mathrm{u}$ pravoj količini, pod pravim uslovima, od pravog isporučioca, $\mathrm{u}$ pravo vreme, sa pravom uslugom i na pravom mestu, na osnovu čega se zaključuje da upravo proces nabavke obezbeđuje kontinuitet realizacije svih ostalih procesa $u$ organizaciji. Takođe, detaljna analiza literature $u$ vezi ključnih indikatora performansi je pokazala da su ključne mere za praćenje performansi lanca snabdevanja kvalitet proizvoda (kroz usaglašenost kvaliteta, pouzdanost kvaliteta i kvalitet krajnjeg proizvoda), isporuka (kroz vreme isporuke, pouzdanost isporuke, frekvencija isporuke, sinhronizacija isporuka, brzina isporuke) i troškovi transporta (kroz upoređivanje ostvarenih troškova transporta dopreme - inbound i troškova transporta otpreme - outbound, kao i njihovo učešće u ukupnim troškovima transporta, i upoređivanje redovnih i vanrednih inbound i outbound troškova).

S obzirom na to da ove mere opisuju performanse izvan organizacionih granica i mere performanse celokupnog lanca snabdevanja, uključujući veze i prema dobavljačima i prema kupcima, preduslov za merenje i analizu ključnih perfomransi lanca snabdevanja je postojanje informacionog sistema koji prati poslovanje, pre svega, proces nabavke, proces prodaje, proces transporta i proces reklamacije kupaca, jer je iz takvog sistema moguće automatski doći do napred odabranih ključnih indikatora performansi.

Za merenje performansi definisanog lanca snabdevanja odabrani su sledeći ključni indikatori performansi za kvalitet proizvoda, kvalitet isporuka i transport:

- ključni indikatori performansi dobavljača: isporuka na vreme od dobavljača (SOTD), reklamacije iz reklamacionog zapisnika prema dobavljaču (SDMR), udeo neusaglašenih delova na milion proizvedenih od dobavljača (SPPM), troškovi lošeg 
kvaliteta dobavljača (STLK), troškovi transporta inbound (redovni troškovi - TTIr i vanredni troškovi - TTIv) $\mathrm{i}$

- ključni indikatori performansi organizacije prema kupcu: isporuka na vreme prema kupcu (COTD), reklamacije iz reklamacionog zapisnika od kupca (CDMR), udeo neusaglašenih delova na milion proizvedenih isporučenih kupcu (CPPM), troškovi lošeg kvaliteta prema kupcu (CTLK), troškovi transporta outbound (redovni - TTOr i varedni troškovi - TTOv).

Na ovaj način organizacija je u mogućnosti da prati i meri performanse vezane sa svog dobavljača i svoj proces nabavke, ali i da prati i meri svoje performanse vezane za svoj proces prodaju, koja, zapravo, predstavlja vezu sa procesom nabavke njenog kupca i na taj način, kroz ocenu svog procesa isporuke dobije informacije o performansama procesa nabavke kupaca. Ovo dalje omogućava da se mere, prate i analiziraju performanse sekvence dobavljač - organizacija - kupac u lancu snabdevanja, čime se postiže unapređenje performansi poslovnih procesa u lancu snabdevanja.

\section{Modeliranje podsistema, ključnih procesa i klasa podataka}

$\mathrm{Na}$ osnovu definisanih zahteva stakeholder-a (menadžmenta, vlasnika, kupaca, dobavljača i OEM-a), definisane mape poslovnih procesa $u$ e-lancima snabdevanja, razvijenog modela za unapređenje poslovnih procesa, izvršeno je modeliranje ključnih procesa $u$ e-lancima snabdevanja. Za razvoj modela procesa korišćeni su:

- BSP metod, čiji su izlaz definisani logički podsistemi i ključni procesi i klase podataka i

- SSA metod, čiji su izlazi dekomponovani dijagrami tokova podataka (kontekstni, korenski i dijagram primitivnih funkcija).

Na bazi formirane matrice procesi/klase podataka, definisani su sledeći logički podsistemi: podsistem nabavka (u okviru njega podsistem ugovaranja nabavke, podsistem planiranja nabavke, podsistem realizacije nabavke, podsistem merenja performansi i ocenjivanja isporučilaca i podsistem merenja performansi procesa nabavke), podsistem prodaje (u okviru njega podsistem za merenje performansi prodaje) i podsistem logistike ( $u$ okviru njega podsistem za merenje performansi procesa transporta).

Logički podsistemi sadrže tokove podataka/skladišta podataka koje sistemi nabavke, prodaje i logistike razmenjuju interno sa ostalim podsistemima $\mathrm{u}$ organizaciji, kao i eksterno sa poslovnim partnerima. Takođe, sadrže i pripadajuće ključne procese koji stvaraju, koriste i ažuriraju određenu dokumentaciju. U matrici su prikazani samo novi procesi kojima se unapređuje postojeće stanje i koji će razvojem novog sistema doprineti unapređenju performansi poslovnih procesa u e-lancima snabdevanja (Tabela 2).

Za razvoj sistema za merenje i unapređenje performansi poslovnih procesa u lancima snabdevanja, a na osnovu već definisanih procesa u okviru nabavke, prodaje i logistike, definisana je hijerarhija odvijanja procesa po nivoima, kao i međusobna uslovljenost procesa, uz pomoć matrice proces/proces (Tabela 3).

Za potrebe razvoja modela za unapređenje poslovnih procesa $u$ e-lancima snabdevanja analizirane su proizvodne organizacije $\mathrm{u}$ automobilskoj industriji koje imaju uveden ISO/TS 16949 standard koji garantuje poslovanje po procesnom pristupu i postojanje uređenih poslovnih procesa. Za posmatrane organizacije izvršena je dekompozicija tri ključna procesa (nabavka, prodaja i logistika), gde su procesi dekomponovani do nivoa koji su neophodni za analizu, realizaciju i merenje performansi procesa $u$ lancu snabdevanja. Za opisivanje tokova odvijanja svakog procesa, sa prikazanim relacijama između procesa, procesa i izvorišta, procesa i odredišta, kao i procesa $\mathrm{i}$ internih skladišta podataka korišćeni su dijagrami toka podataka. Formiranje dijagrama toka podataka realizovano je pomoću (Slike 2, 3, 4 i 5):

- dijagrama konteksta (0-ti nivo),

- korenskog dijagrami (dijagram srednjeg nivoa),

- dijagrama primitivnih funkcija na najnižem nivou.

Modeliranje poslovnih procesa u lancima snabdevanja realizovano je pomoću softverskog alata BPwin, alata za modeliranje i analizu složenih poslovnih procesa. 
Tabela 2 Logički podsistemi i ključni procesi i klase podataka u e-lancima snabdevanja

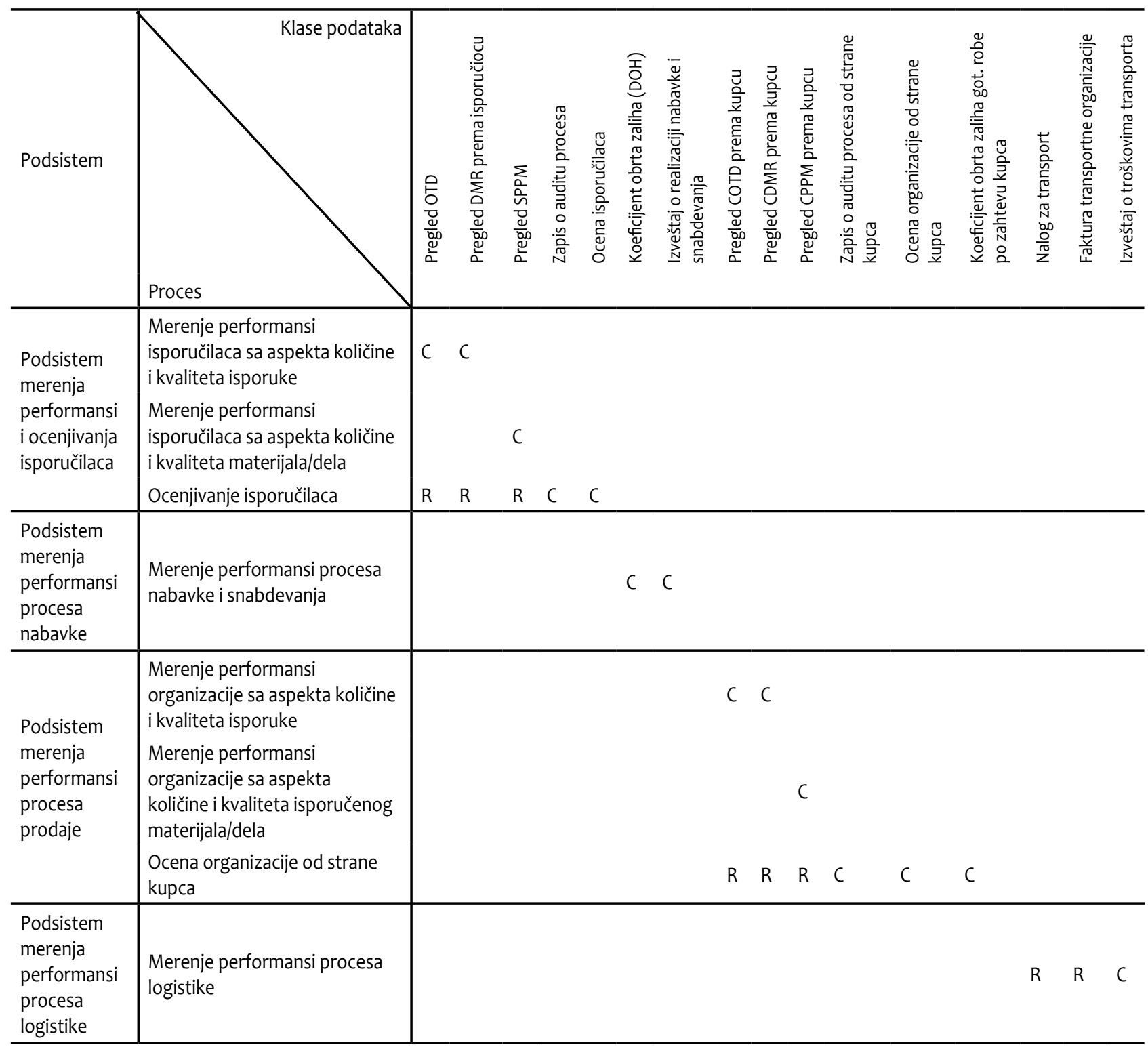

Izvor: Autor

\section{Modeliranje podataka u e-lancima snabdevanja}

Jedan od važnih delova analize sistema je konstrukcija stabilnog i potpunog modela podataka u posmatranom poslovnom području. Organizacija koristi u svojim transakcionim procesima više stotina tipova podataka. Model podataka je sredstvo pomoću kojeg se postiže logičko tumačenje podataka u određenoj oblasti i omogućava da se shvati informacioni sadržaj podataka. On se, dakle, može shvatiti kao skup struktura podataka i operacija nad tim strukturama za određivanje logičke strukture baze podataka i dinamičko modeliranje određene oblasti stvarnosti.

U procesu modeliranja podataka se polazi od modela organizacije dobijenog $\mathrm{u}$ fazi strategijskog informacionog planiranja. Model podataka nastaje tokom detaljnog modeliranja procesa, analize tokova podataka i dokumenata i identifikovanih informacionih potreba koji su značajni za konkretno poslovno područje. 
Tabela 3 Matrica proces/proces

\begin{tabular}{|c|c|c|c|c|c|c|c|c|c|c|c|c|c|c|}
\hline Proces & 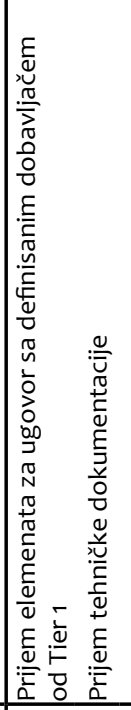 & 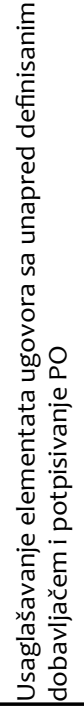 & 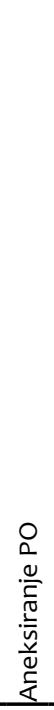 & 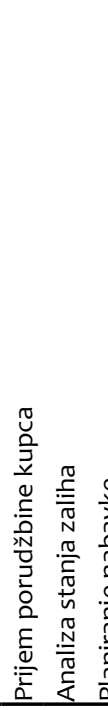 & 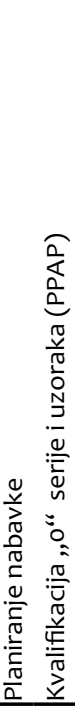 & 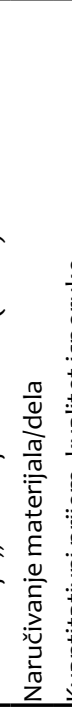 & 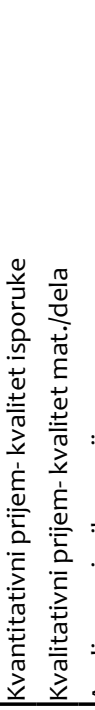 & 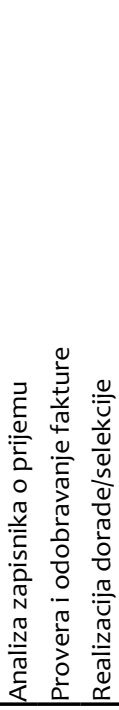 & 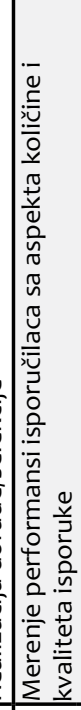 & 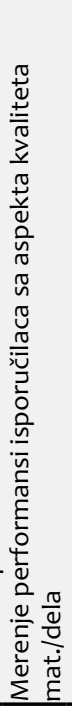 & 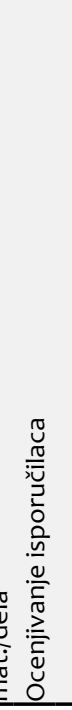 & 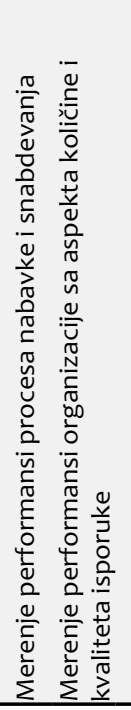 & 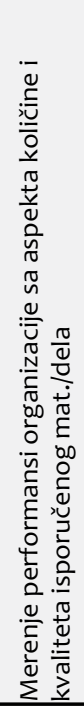 & 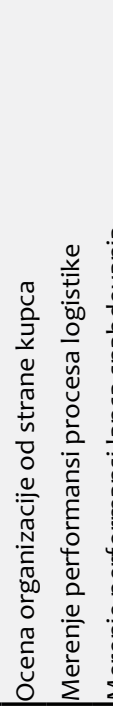 \\
\hline $\begin{array}{l}\text { Prijem elemenata za ugovor sa defini- } \\
\text { sanim dobavljačem od Tier } 1\end{array}$ & 1 & 1 & 1 & & & & & & & & & & & \\
\hline Prijem tehničke dokumentacije & o & 1 & 1 & & & & & & & & & & & \\
\hline $\begin{array}{l}\text { Usaglašavanje elementata ugovora } \\
\text { sa unapred definisanim dobavljačem i } \\
\text { potpisivanje ugovora }\end{array}$ & o & & 1 & 11 & 1 & 1 & & 1 & 1 & 1 & 1 & 1 & & \\
\hline Aneksiranje ugovora & & o & & 11 & 1 & 1 & & 1 & 1 & 1 & 1 & 1 & & \\
\hline Prijem porudžbine kupca & & & o & & 1 & & & & 1 & 1 & & & & \\
\hline Analiza stanja zaliha & & & & o & 1 & & & & & & & & & \\
\hline Planiranje nabavke & & & & o & 1 & 1 & & & & & & 1 & & \\
\hline Kvalifikacija „o“ serije i uzoraka (PPAP) & & & & c & 0 & 1 & 1 & & & & & & & \\
\hline Naručivanje materijala/dela & & & & & o & r & 11 & 1 & & & & 1 & & \\
\hline Kvantitativni prijem- kvalitet isporuke & & & & & & o & 1 & 11 & & & & 1 & & \\
\hline Kvalitativni prijem- kvalitet mat./dela & & & & & & & o & 11 & & & & 1 & & \\
\hline Analiza zapisnika o prijemu & & & & & & & 0 & 11 & 1 & 1 & & & & \\
\hline Provera i odobravanje fakture & & & & & & & & o & & & & 1 & & \\
\hline Realizacija dorade/selekcije & & & & & & & & o & 1 & & & & & \\
\hline $\begin{array}{l}\text { Merenje performansi isporučilaca sa } \\
\text { aspekta količine i kvaliteta isporuke }\end{array}$ & & & & & & & & o & & & 1 & & & 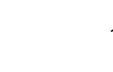 \\
\hline $\begin{array}{l}\text { Merenje performansi isporučilaca sa } \\
\text { aspekta kvaliteta mat./dela }\end{array}$ & & & & & & & & & o & & 1 & & & 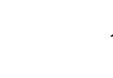 \\
\hline Ocenjivanje isporučilaca & & & & & & & & & & o & & 1 & & 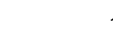 \\
\hline $\begin{array}{l}\text { Merenje performansi procesa nabavke } \\
\text { i snabdevanja }\end{array}$ & & & & & & & & & & & o & & & 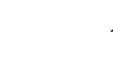 \\
\hline $\begin{array}{l}\text { Merenje performansi organizacije sa } \\
\text { aspekta količine i kvaliteta isporuke }\end{array}$ & & & & & & & & & & & & o & & 1 \\
\hline $\begin{array}{l}\text { Merenje performansi organizacije sa } \\
\text { aspekta količine i kvaliteta isporučenog } \\
\text { mat./dela }\end{array}$ & & & & & & & & & & & & o & & 1 \\
\hline Ocena organizacije od strane kupca & & & & & & & & & & & & & o & 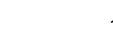 \\
\hline Merenje performansi procesa logistike & & & & & & & & & & & & & & 0 \\
\hline $\begin{array}{l}\text { Merenje performansi lanca snab- } \\
\text { devanja }\end{array}$ & & & & & & & & & & & & & & o \\
\hline
\end{tabular}

1- prethodi procesu 0 - sledi proces

Izvor: Autor 


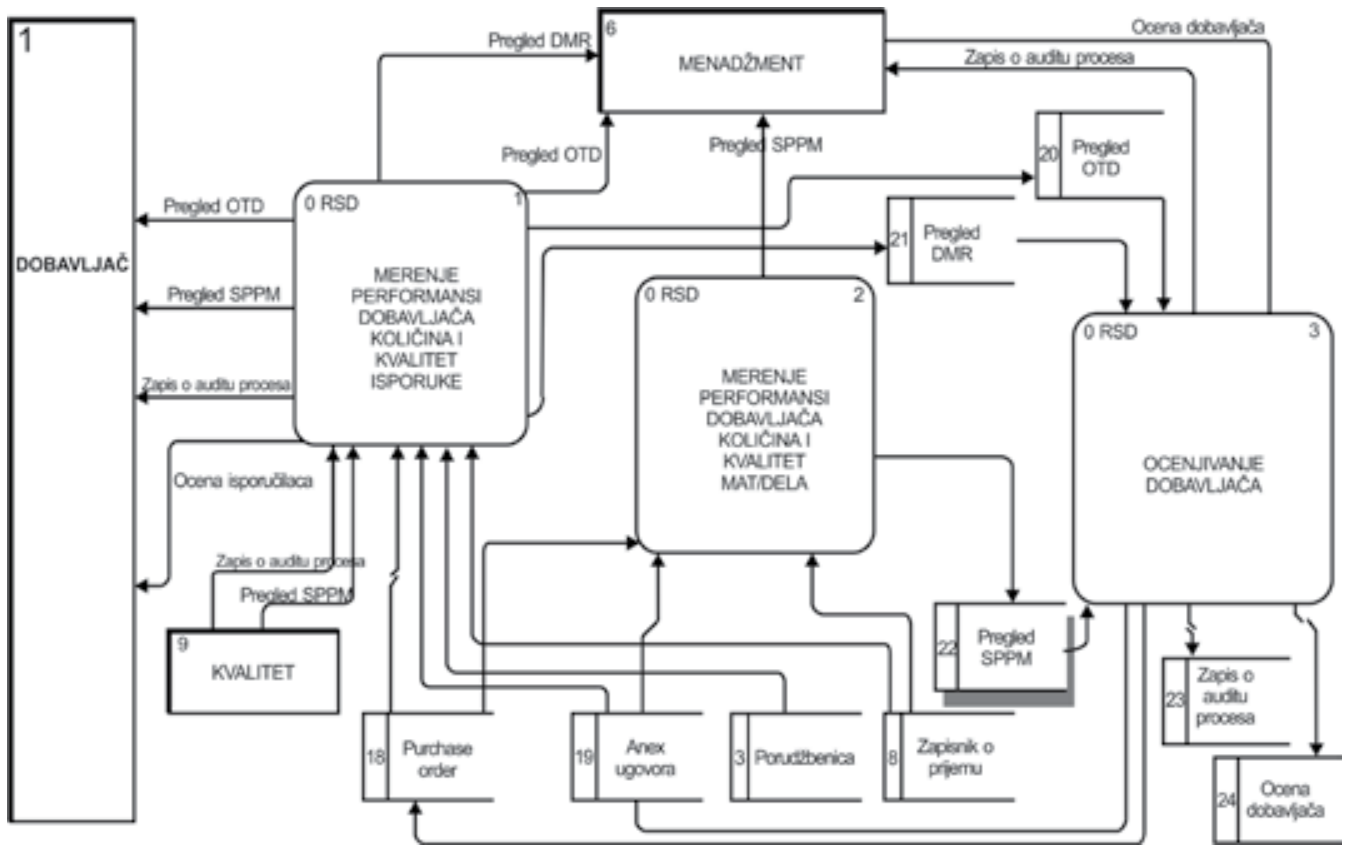

Slika 2 Dijagram toka podataka - Merenje performansi i ocenjivanja isporučilaca

Izvor: Autor

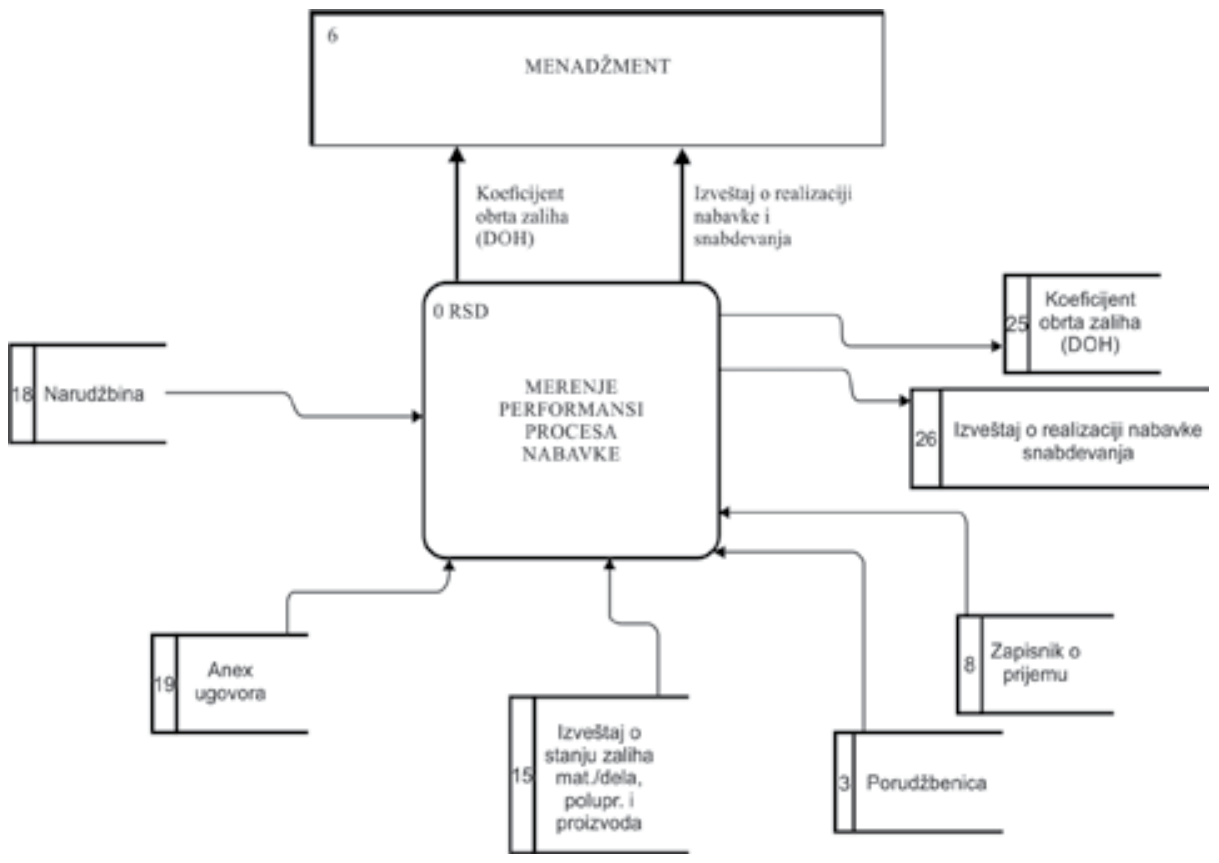

Slika 3 Dijagram toka podataka - Merenje performansi procesa nabavke 


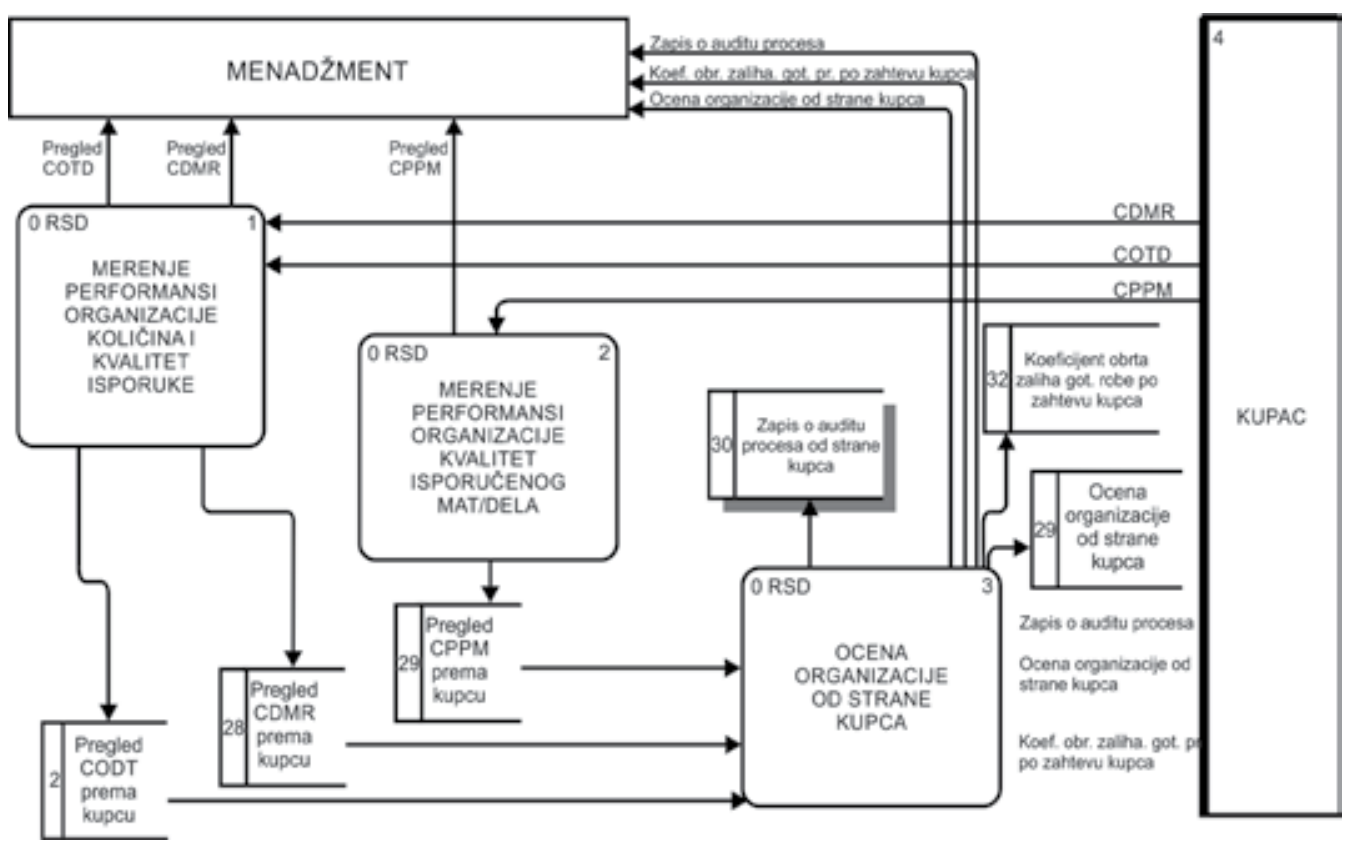

Slika 4 Dijagram toka podataka - Merenje performansi procesa prodaje

Izvor: Autor

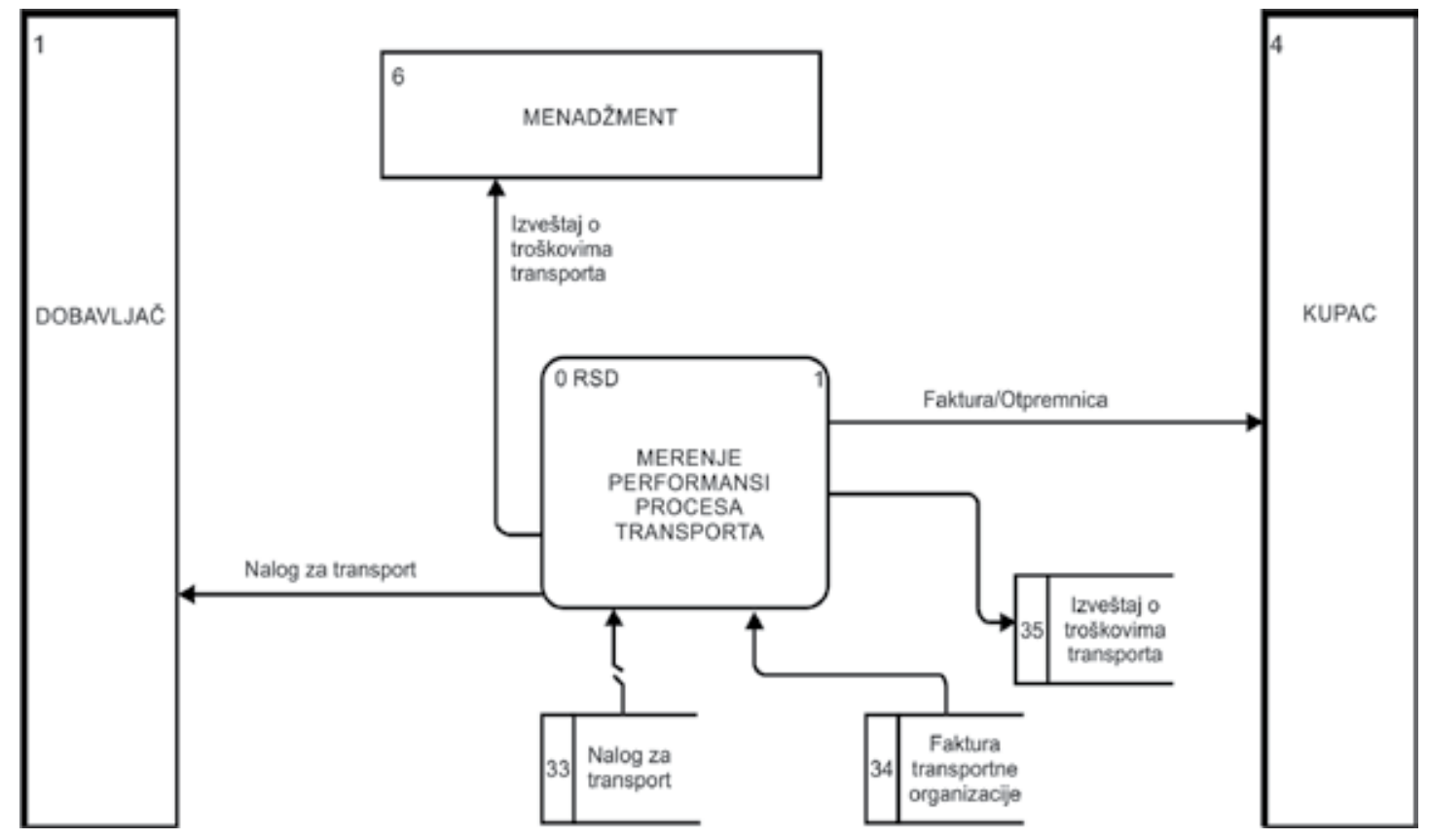

Slika 5 Dijagram toka podataka - Merenje performansi procesa logistike

Izvor: Autor 
Procedura modeliranja podataka sprovedena je $\mathrm{u}$ tri koraka:

- identifikacija svih tipova entiteta na bazi: rezultata modeliranja procesa, rezultata analize tokova podataka, tokova i sadržaja dokumenata, rezultata analize različitih aplikacija, rezultata analize traženih informacionih potreba korisnika;

- utvrđivanje veze i tipova veze između entiteta, kao i predstavljanje modela dijagramom zavisnosti entiteta;

- utvrđivanje relevantnih obeležja za svaki tip entiteta, osobina obeležja i određivanje obeležja kandidata za primarni ključ.

Osnovu za transformaciju modela procesa $\mathrm{u}$ model podataka čine tokovi podataka i skladišta podataka koji predstavljaju fundamentalne karakteristike sistema, odnosno, stanje sistema $\mathrm{u}$ različitim vremenskim intervalima. Na ovaj način svaki tok podataka/skladište podataka se transformiše $u$ model podataka koga čine entiteti koji su međusobno hijerarhijski povezani.

Na osnovu identifikovanih procesa i skladišta procesa u modeliranju procesa u e-lancima snabdevanja i ključnih indikatora performansi i parametara optimizacije dobijenih pomoću AHP metode, definisani su atributi kao ključna svojstva za modeliranje podataka u e-lancima snabdevanja.

Logički model podataka za unapređenje poslovnih procesa u e-lancima snabdevanja, urađen je pomoću softverskog alata ERwin (Slika 6).

Razvijeni model podataka predstavljao je osnovu za dizajniranje baze podataka pomoću odgovarajućeg sofvera za upravljanje bazama podataka. Krajnji rezultat bio je razvijen prototip aplikativnog softvera, kao i razvijen prototip Web aplikacije za unapređenje poslovnih procesa u e-lancima snabdevanja. Time je omogućeno svim članicama lanaca snabdevanja uvid

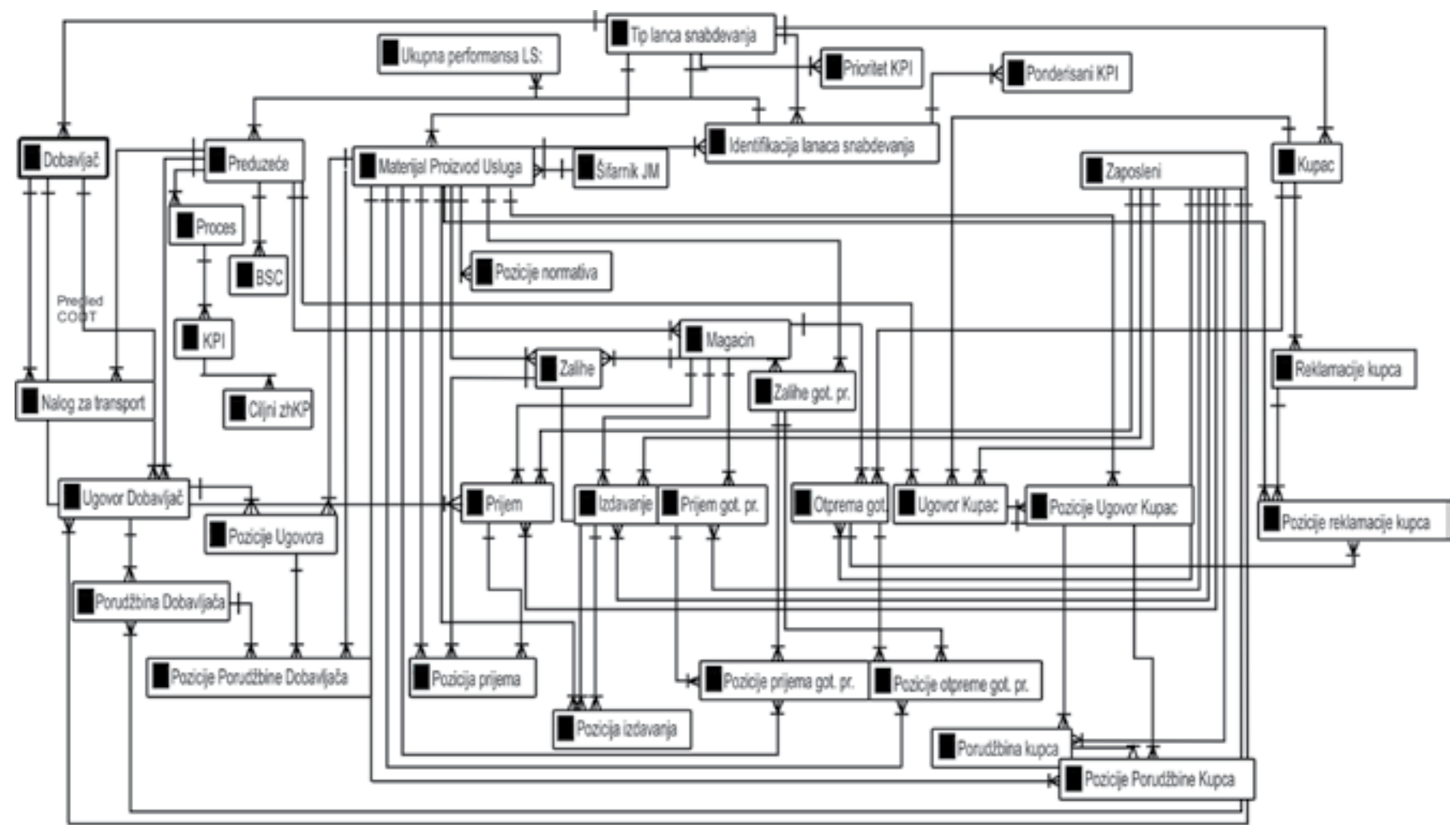

Slika 6 Model podataka za unapređenje poslovnih procesa u e-lancima snabdevanja

Izvor: Autor 
u kretanje ključnih indikatora performansi i ukupne performanse lanca snabdevanja kroz poznavanje prioriteta i pondera KPI za različite tipove lanaca snabdevanja i kroz praćenje ciljnih i trenutnih vrednosti ključnih indikatora performansi poslovnih procesa u različitim tipovima lanaca snabdevanja.

\section{REZULTATI ISTRAŽIVANJA}

Razvijeni prototip Web aplikacije testiran je na organizacijama članicama lanaca snabdevanja $u$ automobilskoj industriji. Nakon perioda testiranja aplikativnog softvera, sprovedeno je istraživanje sa ciljem da se ispitaju polazne hipoteze.

U okviru ovog istraživanja ispitivan je uticaj modeliranja poslovnih procesa i performansi na unapređenje performansi ključnih poslovnih procesa $u$ e-lancima snabdevanja, analiziran je uticaj unapređenja performansi ključnih poslovnih procesa na efikasnost i kvalitet e-lanaca snabdevanja. Takođe, istraživanje je bilo usmereno na ispitivanje uticaja unapređenja performansi poslovnih procesa na efikasnost $i$ kvaliteta-lanaca snabdevanja, kao i u kojoj meri bi primena razvijenog menadžment informacionog sistema za unapređenje poslovnih procesa u e-lancima snabdevanja, doprinela većoj efikasnosti i kvalitetu lanaca snabdevanja.

Empirijsko istraživanje je sprovedeno na uzorku proizvodnih organizacija iz Republike Srbije u periodu septembar-novembar 2015. Osnovni instrument sprovođenja ovog istraživanja bio je anketni upitnik. Prilikom sastavljanja anketnog upitnika poštovane su polazne hipoteze. Anketni upitnik se sastojao od 52 pitanja i bio je usmeren isključivo na menadžment organizacije.

Prilikom potvrđivanja hipoteza korišćene su prosta i višestruka linearna regresija. U Tabeli 4 dati su elementi za proveru polaznih hipoteza.

Tabela 4 Elementi za proveru hipoteza

\begin{tabular}{|c|c|c|c|c|c|}
\hline & $\mathrm{R}$ & $\mathrm{R}^{2}$ & Korigovani $\mathrm{R}^{2}$ & $\mathrm{~F}$ & sig \\
\hline $\begin{array}{l}\text { Uticaj modeliranja poslovnih procesa i } \\
\text { performansi na unapređenje performansi } \\
\text { ključnih poslovnih procesa u e-lancima } \\
\text { snabdevanja }\end{array}$ & 0,767 & 0,588 & 0,583 & 115,701 & 0,000 \\
\hline $\begin{array}{l}\text { Uticaj primene Web baziranih informacio- } \\
\text { no-komunikacionih rešenja na unapređenje } \\
\text { performansi ključnih poslovnih procesa u } \\
\text { e-lancima snabdevanja }\end{array}$ & 0,612 & 0,374 & 0,366 & 48,425 & 0,000 \\
\hline $\begin{array}{l}\text { Uticaj unapređenje performansi ključnih } \\
\text { poslovnih procesa u e-lancima snabdevanja } \\
\text { na efikasnost i kvalitet e-lanaca snabdevanja }\end{array}$ & 0,935 & 0,875 & 0,874 & 567,496 & 0,000 \\
\hline
\end{tabular}

Izvor: Autor

Postupkom analize regresionog modela, koji je obuhvatio, između ostalog, određivanje statistika i mera reprezentativnosti regresionog modela i testiranje hipoteza o značajnosti regresione veze, utvrđena je statistička značajnost uticaja primene modeliranja poslovnih procesa i performansi i primene Web baziranih informaciono-komunikacionih rešenja na unapređenje performansi ključnih poslovnih procesa u e-lancima snabdevanja, kao i statistička značajnost uticaja unapređenja performansi ključnih poslovnih procesa na efikasnost i kvalitet e-lanaca snabdevanja.

\section{ZAKLJUČAK}

Razvijeni prototip menadžment informacionog sistema predstavlja sistem za podršku odlučivanju i omogućava menadžmentu da identifikuje, strukturira i 
reši polustrukturirane i nestrukturirane probleme i da napravi izbor između različitih alternativa. Primenom razvijenog informacionog sistema menadžment brzo i jednostavno dolazi do informacija o ključnim idikatorima performansi za različite poslovne procese $\mathrm{u}$ različitim tipovima lanaca snabdevanja i vrši evaluaciju i rangiranje lanaca snabdevanja.

Pored navedenog, razvijeni menadžment informacionog sistema omogućava strategijskom menadžmentu simulacije seta ključnih indikatora performansi karakterističnog za određeni tip lanca snabdevanja, u cilju optimizacije i povećanja ukupne performanse lanca snabdevanja. Dakle, postoji mogućnost simulacija različitih vrednosti svakog ključnog indikatora performansi u setu i analize njegovog uticaja na ukupnu performansu lanca snabdevanja. Takođe, moguća je simulacija uporedo i za druge lance snabdevanja u cilju postizanja optimalnih performansi lanaca snabdevanja.

Dakle, ovakav sistem za podršku odlučivanju u funkciji je donošenja odluka na svim nivoima odlučivanja, ali je od posebnog značaja za više nivoe. Kroz mogućnost analize osetljivosti korisnici sistema ispituju posledičnost pojedinih alternativnih pravaca ili ispituju posledice koje mogu nastupiti prilikom promene uticajnih faktora na izabranu alernativu.

Pored toga što razvijeni menadžment informacioni sistem, olakšava horizontalni protok informacija, ovaj sistem za podršku odlučivanju podržava i vertikalne informacione tokove $i$ tako pomaže integraciju informacija koje se koriste na različitim organizacionim i upravljačkim nivoima jedne organizacije, ali i većeg broja organizacija koje su članice konkretnog lanca snabdevanja, što je omogućeno razvojem Web bazirane podrške ovom sistemu.

Interface sa OEM-om, kupcima i dobavljačima podrazumeva razmenu prikazanih pokazatelja i informacija, dostupnih preko Web-a, i to na zahtev korisnika $u$ unapred dogovorenoj formi. Primena ovog modela merenja performansi poslovnih procesa u e-lancima snabdevanja dovela je do unapređenja poslovnih procesa duž celog lanca sndabdevanja, jer je kroz razvijeni menadžment informacioni sistem ostvarena integrisana, istovetna, transparentna metrika i sistem merenja performansi. Na ovaj način olakšana je integraciju informacija iz pojedinih podsistema za strategijsko odlučivanje i ostvarena automatizacija strategijskog planiranja i predviđanja na nivou lanaca snabdevanja.

$S$ obzirom na izrazitu interdisciplinarnost i multidisciplinarnost istraživanja, a saglasno definisanom predmetu i cilju istraživanja, postavljenim hipotezama i izabranim metodama istraživanja, teorijsko-metodološki i praktični doprinos ovog rada ogleda se u unapređenju konceptualnih modela procesa u e-lancima snabdevanja, razvoju modela za unapređenje performansi poslovnih procesa u e-lancima snabdevanja i razvoju modela menadžment informacionog sistema za podršku ključnim poslovnim procesima u e-lancima snabdevanja.

Prilikom razvoja ovog modela menadžment informacionog sistema predmet analize nisu bili i drugi poslovni procesi u lancima snabdevanja, što predstavlja ograničenje sprovedenog istraživanja. U kontekstu navedenog ograničenja buduća istraživanja će biti usmerena na analizu i drugih poslovnih procesa u lancima snabdevanja, tako da će budući razvoj značiti njihovo integrisanje u razvijeni model i Web aplikaciju za unapređenje performansama lanaca snabdevanja. Takođe, postojeći model će biti proširen i drugim ključnim indikatorima performansi, čime će se postići da, ukupna performansa lanca snabdevanja, koja bi $\mathrm{u}$ tom slučaju bila zavisna od većeg broja ključnih indikatora performansi, bude mera koja će još bolje oslikati efikasnost i kvalitet lanaca snabdevanja, i kao takva poslužiti za evaluaciju i rangiranje različitih tipova lanaca snabdevanja.

\section{ZAHVALNICA}

Ovaj rad je deo interdisciplinarnog i multidisciplinarnog istraživačkog Projekta (br. 44010), koji finansira Ministarstvo prosvete, nauke i tehnološkog razvoja Republike Srbije.

\section{REFERENCE}

Arsovski, Z. (2013). Determinants of the implementation of information and communication technologies in clusters of enterprises. Economic horizons, 15(2), 107-123. doi: 10.5937/ ekonhor1302103A 
Bai, C., \& Sarkis, J. (2012). Supply chain performancemeasurement system management using neighbourhood rough sets. International Journal of Production Research, 50(9), 2484-2500. doi: 10.1080/00207543.2011.581010

Bai, C., Sarkis, J., Wei, X., \& Koh, L. (2012). Evaluating ecological sustainable performance measures for supply chain management. Supply Chain Management: An International Journal, 17(1), 78-92. doi: $10.1108 / 13598541211212221$

Cabral, I., Grilo, A., \& Cruz-Machado, V. (2012). A decision-making model for lean, agile, resilient and green supply chain management. International Journal of Production Research, 50(17), 4830-4845. doi: 10.1080/00207543.2012.657970

Chan, F. T. S., \& Qi, H. J. (2003). An innovative performance measurement method for supply chain management. Supply chain Management - An International Journal, 8(3), 209-223. doi: $10.1108 / 13598540310484618$

Christopher, M., \& Towill, D. (2000). Supply chain migration from lean and functional to agile and customised. Supply Chain Management - An International Journal, 5(4), 206-213. doi: $10.1108 / 13598540010347334$

Christopher, M., Peck, H., \& Towill, D. (2006). A taxonomy for selecting global supply chain strategies. The International Journal of Logistics Management, 17(2), 277-287. doi:10.1108/09574090610689998

De Toni, A., Nassimbeni, G., \& Tonchia, S. (1994). Service dimensions in the buyer-supplier relationship: A case study. International Journal of Physical Distribution \& Logistics Management, 24(8), 4-14. doi: 10.1108/09600039410071235

Genovese, A., Koh, L. S. C., Kumar, N., \& Tripathi, P. K. (2014). Exploring the challenges in implementing supplier environmental performance measurement models: A case study. Production Planning and Control, 25(13-14), 1198-1211. doi: 10.1080/09537287.2013.808839

Gimenez, C., \& Tachizawa, E. M. (2012). Extending sustainability to suppliers: A systematic literature review. Supply Chain Management - An International Journal, 17(5), 531543. doi:10.1108/13598541211258591

Gunasekaran, A., Patel, C., \& McGaughey, E. (2004). A framework for supply chain performance measurement. International Journal of Production Economics, 87(3), 333-347. http://dx.doi.org/10.1016/j.ijpe.2003.08.003

Hayes, R. H., \& Wheelwright, S. C. (1984). Restoring our Competitive Advantage. New York, NY: Wiley.

Holmberg, S. (2000). A systems perspective on supply chain measurements. International Journal of Physical Distribution \& Logistics Management, 30(10), 847-868. doi:10.1108/09600030010351246

Karadgi, S. (2014). A Reference Architecture for Real-Time Performance Measurement-An Approach to Monitor and Control Manufacturing Processes. London, UK: Springer.

Koh, L. S. C., Demirbag, M., Bayuraktar, E., Tatoglu, E., \& Zaim, S. (2007). The impact of supply chain management practices on performance of SMEs. Industrial Management E Data Systems, 107(1), 103-124. doi: $10.1108 / 02635570710719089$

Lambert, D. M. \& Pohlen, R. L. (2001), Supply chain metrics. The International Journal of Logistics Management, 12(1), 1-19, doi: 10.1108/09574090110806190.

Landeghem van, R., \& Persoons, K. (2001). Benchmarking of logistical operations based on a casual model. International Journal of Operations \& Production Management, 21(1-2), 254266. doi: $10.1108 / 01443570110358576$

Mason, J. H., \& Cole, M. H. (2002). Improving electronics manufacturing supply chain agility through outsourcing. International Journal of Physical Distribution \& Logistics Management, 32(7), 610-620. doi: 10.1108/09600030210442612

Morgan, C. (2004). Structure, speed and salience: Performance measurementinthesupply chain. Business Process Management Journal, 10(5), 522-536. doi: 10.1108/14637150410559207

Otto, A., \& Kotzab, H. (2001). Does Supply Chain Management really pay? - Six perspectives to measure the performance of managing a supply chain. European Journal of Operational Research, 144(2), 306-321. doi.org/10.1016/S03772217(02)00396-X

Petroni, A., \& Panciroli, B. (2002). Innovation as a determinant of suppliers' roles and performances: An empirical study in the food machinery industry. European Journal of Purchasing $\mathcal{E}$ Supply Management, 8(3), 135-149. doi.org/10.1016/S09697012(02)00004-7

Robson, I. (2004). From process measurement to performance improvement. Business Process Management Journal, 10(5), 510-521. doi: 10.1108/14637150410559199

Saad, M., \& Patel, B. (2006). An Investigation of supply chain performance measurement in the Indian automotive sector. Benchmarking: An International Journal, 13(1-2), 36-53. doi: 10.1108/14635770610644565

Saaty, T. (2010). Economic forecasting with tangible and intagible criteria: The analytic hierarchy process of measurement and its validation. Economic Horizons, 12(1), 5-45. 
Shepherd, C., \& Günter, H. (2006). Measuring supply chain performance: Current research and future directions. International Journal of Productivity and Performance Management, 55(3-4), 242-258. doi: 10.1108/17410400610653219

Tracey, M., \& Tan, C. L. (2001). Empirical analysis of supplier selection and involvement, customer satisfaction, and firm performance. Supply Chain Management - An International Journal, 6(4), 174-188. doi: 10.1108/EUM0000000005709

Vereecke, A., \& Muylle, S. (2006). Performance improvement through supply chain collaboration in Europe. International Journal of Operations \& Production Management, 26(11), 11761198. doi: $10.1108 / 01443570610705818$

Primljeno 10. novembra 2016, nakon revizije, prihvaćeno za publikovanje 26. decembra 2016. Elektronska verzija objavljena 30. decembra 2016.

Dragana Rejman Petrović je docent na Ekonomskom fakultetu Univerziteta u Kragujevcu, gde je doktorirala iz uže naučne oblasti statistika i informatika. Izvodi nastavu na nastavnom predmetu Informacioni sistemi. Ključne oblasti njenog istraživačkog rada su poslovni i menadžment informacioni sistemi, upravljanje poslovnim procesima, upravljanje lancima snabdevanja i operativni menadžment.

\title{
BUSINESS PROCESS IMPROVEMENT IN E-SUPPLY CHAINS
}

\author{
Dragana Rejman Petrovic \\ University of Kragujevac, Faculty of Economics, Kragujevac, The Republic of Serbia
}

The development of a model to improve business processes in e-supply chains involves the use of a process approach to and a methodology for information systems development and includes the definition of the requirement, logical key process modeling with the defined information flow within the logical subsystem, logical data modeling, the logical network and data distribution modeling, and the logical interface modeling in order to meet different users' needs. In doing so, a variety of methods and techniques for the different development stages of management information systems are used, namely: the business process management, the business process performance management and the analytic hierarchy process as a method for multiple-criteria decision making. This paper analyzes business processes and different types of supply chains in the automotive industry, as the representative of complex systems. Based on the selected key business processes and key performance indicators of business processes, the analytic hierarchy process model is developed, followed by their optimization. The result is the management information system model intended to improve the key business processes in e-supply chains. The research results show that the performance improvement of business processes in e-supply chains, the application of the model to improve the key business processes and the application of Web-based information and communication solutions affect the efficiency and quality of e-supply chains.

Keywords: supply chains, business processes, performance measurement, management information systems 